\title{
Edipo y Gaia \\ EL TEMA DE LA MADRE TIERRA EN EL ORÁCULO DE DELFOS
}

\author{
Oedipus and Gaia \\ MOTHER EARTH TOPIC IN THE ORACLE OF DELPHI
}

\author{
Angel luis CAsquillo Fumanal*
}

\begin{abstract}
RESUMEN
Cuando el oráculo de Delfos proclamó destino de Edipo el casarse con su madre, éste entendió de forma unívoca que la Pitia se refería a su madre biológica. Pero la equivocidad (y la analogía) era una característica propia de Delfos, que empleaba conceptos - como el de madre - de forma ambigua: El término madre en la ideología délfica podía referirse analógicamente a la Madre

Tierra. Si Edipo hubiera entendido el oráculo de forma analógica, su destino podría haber sido distinto.

PALABRAS CLAVE:

Oráculo, Delfos, ambigüedad, madre biológica, Madre Tierra, Edipo, sueño de Edipo, interpretación de Yocasta.
\end{abstract}

\begin{abstract}
When Delphic oracle proclaimed Oedipus destiny marrying his own mother, he understood in an univocal way that Pythia meant his biological mother. But aequivocity (or analogy) was characteristic of Delphi, which employed concepts - as mother- in an ambiguous way. The word mother, in Delphic ideology, could mean Mother Earth. If Oedipus had understood Delphic oracle in an analogical way, his destiny could have been different.
\end{abstract}

\section{KEYWORDS:}

Oracle, Delphi, ambiguity, biological mother, Mother Earth, Oedipus, Oedipus dream, locasta's interpretation.

\section{AMBIGÜEDAD E INEXORABILIDAD DEL ORÁCULO.}

Edipo, en el drama de Sófocles, entiende el oráculo de Apolo de forma unívoca: su destino es casarse con su madre y matar a su propio padre. Edipo entiende -y en base a esta acepción semántica se desarrollan los episodios del drama

\footnotetext{
•I.E.S. Juana de Castilla. C/ Máiquez, 6, 4ํD, 28009-Madrid. E-mail: luiscfumanal @ hotmail.com
} 
sofócleo- que su madre es la mujer (Mérope) que, según piensa él, le dio a luz (en Corinto). Y, paralelamente, cuando Edipo descubra su verdadera identidad y su auténtica biografía, Yocasta, la reina de Tebas, con la que está casado, pasará a ser la madre carnal que de acuerdo con Layo hizo abandonar al recién nacido Edipo en las faldas del monte Citerón.

Pero el drama de Sófocles pasa por alto un dato, que a todos parece consustancial al oráculo: la ambivalencia proverbial que caracteriza la esencia misma del lenguaje oracular de Delfos. ¿Acaso había que entender en sentido literal las palabras de la sacerdotisa de Apolo? Todos los textos antiguos convergen precisamente en lo contrario. La oscuridad de Apolo (Loxias) era proverbial, y sólo se podía comparar a la del filósofo Heráclito, llamado expresamente skoteinós, el Oscuro. "Adivinanzas dices, oh tú, o compones acertijos: pues tal como Loxias, nada dices a las claras». Así habla un campesino dirigiéndose a Heráclito en uno de los famosos diálogos del sofista Luciano. ${ }^{1}$

Plutarco, el autor antiguo que más expresa y extensamente se ha ocupado de Delfos y de su oráculo, hace mención concreta a la oscura ambigüedad de todo lo relacionado con Apolo, el dios délfico: «la mayor parte de las cuestiones concernientes al dios se hallan envueltas en enigmas» (PLUT, La E de Delfos, 385 c). Y, por supuesto, entre lo relativo al dios lo más ambiguo son su oráculos: «que el dios es sumamente dialéctico, la mayoría de los oráculos lo demuestran; pues sin duda es propio del mismo tanto el resolver como el crear ambigüedades (amphibolías)» (ibi. 386 E). Y Plutarco mismo, a continuación da una razón de tal anfibología: «Al pronunciar oráculos ambiguos, el dios lo que trata es de desarrollar y confirmar la dialéctica como necesaria para los que quieran entenderle correctamente» (ibid.). ${ }^{2}$

El texto más significativo de cuantos ponderan la ambigüedad esencial del oráculo de Delfos es un testimonio de Heráclito mismo documentado por Plutarco (de Pyth. or. 327A). El filósofo presocrático Heráclito hace a Apolo modelo de su propia oscuridad con estas palabras: «El señor de quien es el oráculo de Delfos ni

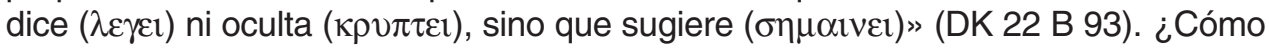
entender el «decir», el «ocultar» y el «señalar» de Apolo? En todos los textos que ponderan la ambigüedad del oráculo délfico hay que combinar el elemento irracional —nocturno, oscuro- que conviene a Gaia, con el elemento racional —luminoso, diurno- que cuadra con Apolo. Agustín García Calvo lo ha puesto bien de relieve en su comentario al texto de Heráclito (DK 22 B 93), en el que -entre la claridad que corresponde al «decir» ( $\lambda \varepsilon \gamma \varepsilon \mathrm{l}$ ) de Apolo y la oscuridad que corre-

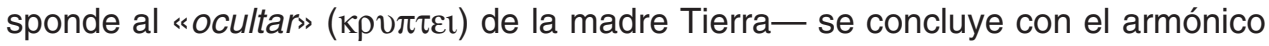

1 LUC. Vitarum auctio, 14. Texto citado al lado de DK 22 B 93 en García Calvo, Razón común. Heráclito. Lucina, Madrid, 1985.

2 «La proverbial ambigüedad de los oráculos antiguos es referida asimismo en Mor. 407 C-D $<$ Pyth.or. 26), aunque las razones allí aducidas son distintas, de tipo diplomático, en el sentido de evitar a los servidores del templo las posibles represalias por parte de los poderosos que solían consultar, en el caso de una respuesta desfavorable, así como impedir que se enteraran los enemigos» (Francisca Pordomingo Pardo y José Antonio Fernández Delgado, en Plutarco, Moralia VI, Ed. Gredos, Madrid 1995, p. 249, n. 33). 


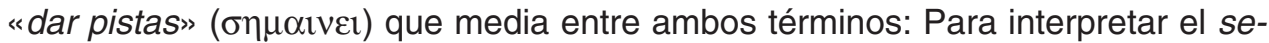
mainei, García Calvo cita un texto paralelo de Estobeo, en que se documenta el fragmento de Heráclito, con la siguiente coletilla: «sino que señalando (alusión al

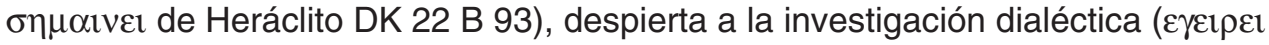
$\pi \rho \circ \delta \iota \lambda \varepsilon \kappa \tau \iota \kappa \eta \nu ~ \varepsilon \rho \varepsilon v v \eta \sigma \imath v)$ a los que escuchan los oráculos» (STOB. Eccl. II, 2,5). La interdependencia de Plutarco y Estobeo es manifiesta.

$\mathrm{Y}$, sin embargo, algunos autores contemporáneos tienden a poner de relieve que las respuestas del oráculo de Delfos no comportaban «ni afabulación ni oscuridad» (CRAHAY, 1956, p.11, respecto a la materia epigráfica) ${ }^{3}$ o al menos no los oráculos históricos, aunque sí la comportasen algunos de los oráculos trasmitidos por historiadores como Heródoto y prácticamente todos los oráculos transmitidos — si no creados— por los autores épico-trágicos (FONTENROSE 1978: 11). ${ }^{4}$

Quizás una explicación de esta contradicción con los testimonios más antiguos (Heráclito, Platón en la «Apología de Sócrates», Plutarco, etc.), que siempre resaltan la oscuridad de los oráculos, está en que las respuestas epigráficas que conocemos -y todas las respuestas no épico-trágicas- están «siempre en estilo indirecto", como refiere el propio Crahay (loc.cit.), lo que seguramente implica ya una reinterpretación de las palabras de la Pitia (posiblemente ambiguas en sí mismas en el estilo directo original).

Plutarco (Moralia) aclara que los antiguos oráculos en verso eran enigmáticos, pero que en su tiempo han pasado a ser en prosa y claros.

Y sin embargo el testimonio histórico de Sócrates, si hemos de creer a Platón en su «Apología», viene a confirmar que el oráculo era enigmático por naturaleza. Aun los oráculos que parecían más claros y unívocos, como el que Querefonte recibió de Apolo acerca de Sócrates, podían resultar ambivalentes y complejos.

El oráculo a que nos estamos refiriendo es, si hemos de creer a Platón, que lo narra en su «Apología de Sócrates», un testimonio histórico. ${ }^{5}$ Querefonte preguntó a Apolo délfico si había en toda Grecia alguien más sabio que Sócrates. La

${ }^{3}$ CRAHAY, Roland. La littérature oraculaire chez Hérodote. Paris. Les Belles Lettres, 1956.

4 FONTENROSE, Josef. Delphic Oracle. Its Responses and Operations. With a catalogue of Responses. University of California Press. Berkeley and Los Angeles 1978.

5 «Aquí, en relació a I'anada a Delfos de Querefont, I'amic i admirador de Sòcrates, cal tenir present un text de Xenofont (Anabasi III, 1, 4-8), que Giovanni Reale (1997:7) fa servir com a prova (contra Gigon 1947 i Montuori 1998) de la historicitat de I'esdeveniment ocorregut a Delfos. (...) i, per tant, de la historicitat en la narració platònica de l'esdeveniment» (BOSCH-VECIANA, Antoni. La saviesa nascuda en el Temple de Delfos: Plató, "Apologia de Sòcrates», 20d8: Lliçó inaugural del curs acadèmic 20062007. Facultat de Teologia de Catalunya, Barcelona, 2006. pág. 36 con n. 64. 
respuesta de la Pitia es de todos conocida: «Sócrates es el más sabio de todos los griegos». Tal respuesta parecía transparente. Pero Sócrates creyó que chocaba con la propia realidad. Cuando Sócrates tuvo noticia de este oráculo, se quedó sorprendido, y preso de una auténtica aporía, pues él no tenía conciencia de ser sabio

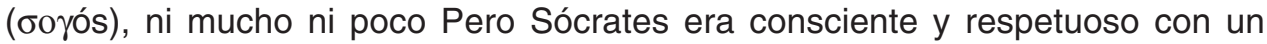
principio: Apolo no podía mentir. Si Apolo lo proclamaba no solamente sabio, sino «el más sabio de todos los griegos», ello tenía que deberse a la ambigüedad misma de la proposición del oráculo. Así se expresa claramente en la «Apología»

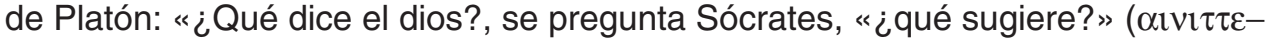
$\tau \alpha$, PLAT. Apolog. 21 b 4), añade Sócrates precisando la forma de decir del dios: «sugiere, dice enigmáticamente ( $\alpha \imath v \imath \tau \tau \varepsilon \tau \alpha \iota$, palabra de la misma raíz que «enigma»< $<\operatorname{lv}(\gamma \mu \alpha>){ }^{6}$

Y Sócrates se dispone a resolver ese enigma: Primero, para darse razón a sí mismo, lo que él toma por una verdadera «refutación» ( $\varepsilon \lambda \varepsilon \gamma \chi o s, ~ e l e n c h u s, ~ P L A T$. Apolog. 21c 1) de las palabras del oráculo, al menos en su tenor literal. Pero Sócrates se propone, en segundo lugar, averiguar el sentido verdadero, aunque enigmático, de las palabras - aparentemente claras- de Apolo, un dios, que no tiene siquiera la posibilidad (ov $\gamma \alpha \rho \theta \varepsilon \mu 1 s \alpha v \tau \varpi, 21 b$ 6-7) de no ser verídico.

Sócrates, quien como hemos dicho no se tiene a sí mismo por sabio en ningún

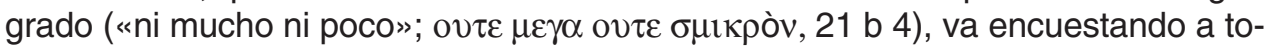
dos sus conciudadanos, para encontrar a alguno más sabio que él. Pero no encuentra, ni siquiera entre los griegos que en principio debieran ser los más sabios —políticos, sofistas... - ninguno que le parezca mínimamente sabio. La conclusión de toda la investigación, a la que llega Sócrates, es esclarecedora: Él se mantiene en su principio de no ser en absoluto sabio («sólo sé que no sé nada»). Aun así es verdad, como dice Apolo, que él es el más sabio de todos los griegos. Pero en una sola cosa es más sabio que todos los demás: que él es consciente de su propia ignorancia. Sólo él sabe «que no sabe nada», y en eso aventaja a todos los otros griegos. ${ }^{7}$

6 Ver CHANTRAINE, Pierre. Dictionnaire étymologique de la langue grecque. Klincksieck. Paris, 1968. s.v. $\alpha \iota v o \zeta$. Para el verbo $\alpha \imath v \imath \sigma \sigma o \mu \alpha \imath=\alpha \imath v \tau \tau o \mu \alpha \imath$ Chantraine sugiere la traducción « parler par énigmes», pero también «dire des paroles difficiles à comprendre» y en concreto «dire des paroles significatives", lo que nos remite al verbo semainein, «significar» en la célebre y paralela sentencia de Heráclito: «El señor del que es el oráculo que está en Delfos ni dice ni oculta sino que sugiere «(«significa»,

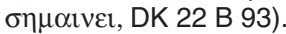

${ }^{7}$ Conviene, aunque sólo sea de paso, poner de relieve el carácter aristocrático de la argumentación que Platón pone a lo largo de toda la «Apología» en boca de Sócrates: El griego común no sabe nada (sólo se exceptuará una «raza de oro», cuya función política Platón desarrolla en otros Diálogos, como la «República»). Dicho de otra forma: el griego medio debe reconocer que no está dotado para la política (ver, ex.gr. el diálogo titulado «Protágoras», sofista que reivindicaba la tesis contraria). La conclusión políticamente in/correcta que Platón pone en boca de Sócrates en su propia «Apología» es la siguiente: «lo que sé (!) es que obrar injustamente y desobedecer al mejor ( $\beta \varepsilon \lambda \tau \imath o ́ v ı$, adjetivo en grado comparativo que se corresponde con el superlativo griego aristôs) es malo y vergonzoso» (29 b 6-7). Toda una apología, pues, del régimen político de la aristocracia, en que los mejores (que sí saben) son los «hombres de oro» o los filósofos. 
Y así se comprueba la ambigüedad del oráculo —aun el que parecía claro-y la veracidad de Apolo. De esta manera la actitud de Sócrates, que no se cree sabio, y que pasa por una situación aporética a la hora de interpretar el oráculo, para no dejar a Apolo por mentiroso, contrasta con la actitud de Edipo, calificada de sofística por Tiresias (ver SOPHOCL. Oed.Tyr. 390-440). Edipo, cuando la Pitia le previene de «casarse con su madre y matar a su padre», interpreta literalmente el oráculo como si Apolo no tuviera para él —un sofista - ni ambigüedades ni secretos. Echa mano así de una sabiduría y de una actitud sofística, de la que volverá a usar cuando tendrá que descifrar - como si de otro oráculo se tratarael enigma de la Esfinge ${ }^{8}$ y de la que se jactará en su lucha con Tiresias en el Episodio 1엉 del «Edipo Rey» de Sófocles: «Y cierto, el enigma de la perra cantora no era para que lo descifrara el primero que viniera, sino que requería adivinación $(\mu \alpha v \tau \varepsilon i \alpha)$... Pero, viniendo yo, el que nada sabía (de oráculos divinos), acabé con la esfinge, acertando con mi talento, no aprendiendo de aves» (ibid. 393-398). Así, pues, Edipo equipara el enigma de la esfinge con el enigma oracular, y antepone su saber sofístico ( $\gamma \omega \omega \mu \eta$, ibid. 398), ${ }^{9}$ con el que él interpreta oráculos (como el de la Pitia acerca de sus verdaderos padres) y enigmas (como el de la Esfinge), al saber mántico de los intérpretes de Apolo, del que él dice -a lo Sócrates pero en materia diversa <e inversa>- «no saber nada» (o $\mu \eta \delta \varepsilon v \varepsilon 1 \delta \omega s$, ibid. 397). ${ }^{10}$

Pero el «sofista» Edipo no puede contrarrestar la ambigüedad de Tiresias y se queja. «¡Qué demasiado enigmáticas $(\alpha \iota v \imath \kappa \tau \alpha)$ y oscuras dices todas las cosas!» (ibid. 439). Tiresias le recrimina una vez más su vana pretensión de ser «eminente en descifrar estas cosas (ibid. 440). ¿Cómo entonces descifrar la ambigüedad consustancial a los oráculos sin ser un dios ni dárselas de "sofista"»?

Como dice Bosch-Veciana (loc.cit., p.49 n.78) a propósito del oráculo de Apolo sobre Sócrates, la actitud racionalmente correcta de Edipo debía haber sido, no pensar que el dios no tenía razón («yo no voy a matar a mi padre ni voy a casarme con mi madre», sencillamente porque voy a evitarlo), ni huir de Apolo y del cumplimiento del oráculo, sino pararse a pensar en qué sentido podía el oráculo ser razonable y el dios ser veraz sin ser destructivo y cruel. Sin duda, el sentido del

8 «Moret (1984) ha subrayado la semejanza de función de la Esfinge con la Pitia (ver RUIPÉREZ, Martín S. El mito de Edipo. Lingüística, psicoanálisis y folklore. Madrid. Alianza, 2006, p. 54).

9 Su saber sofístico es «su talento, $\gamma \omega \mu \eta$, palabra que los sofistas barajaban con la $\tau \varepsilon \chi v \eta$ » (cfr. MÜLLER, I. Handbuch des Klassichen Altertums 1912, VII, p. 646)» (MAYOR, Domingo. Sófocles: Edipo Rey. Edición y estudios. Universidad Pontificia de Comillas. Santander, 1948, p. 61 n. 1). «Los sofistas de entonces, frente a la antigua pasividad del hombre, pendiente del azar de los dioses y del hado, agitaban la idea de que el ingenio humano, experimentado, debía crear sus destinos dominando las circunstancias. En toda la tragedia se trasluce (en éste y otros aspectos) la lucha entre la nueva ideología y las creencias antiguas» (ibid. p. 59 n. 5).

10 Heródoto (hacia el 500 a.C.) aún creía en los oráculos. Sófocles a lo largo del «Edipo Rey» (hacia el 450 a.C.) defiende, sobre todo en boca del coro, la fe en el Apolo délfico. Pero: «La sophistique exerce ensuite une action dissolvante et Euripide rejette presque avec mépris la croyance aux oracles (EURIP. Helena 754 ss.)» (ver SCHEFFER 1943:173). El escepticismo de Eurípides se dirige directamente (y quizás exclusivamente) a los intérpretes del oráculo, y no al dios mismo: "Solamente Febo debería cantar en son profético para los hombres» (EURIP. Phoen. 958-59), contra la opinión de Plutarco, que cita el texto, pero reivindica el derecho de Apolo «a usar servidores e intérpretes mortales» (PLUT. de Pythiae or. 407 d). 
oráculo había de ser acorde con el conjunto de temas de que se ocupaba el rito y el mito délfico. Al mito y ritual délfico correspondía una ideología religiosa y un ideario en un sentido más amplio —lo que también se ha llamado la «propaganda délfica»- ${ }^{11}$ que es de lo que, en buena lógica nos vamos a ocupar a continuación.

\section{EL IDEARIO DÉLFICO}

\subsection{El tema de la madre Tierra}

Dentro del ideario délfico hay que considerar primero aquellas máximas que estaban grabadas en los muros mismos del templo de Apolo. Vamos a tomar en consideración las dos más importantes en relación al tema de la madre Tierra. «Nada en demasía» ( $\mu \eta \delta \varepsilon v \alpha \gamma \alpha v$ ) nos remite a la mesura que era característica del carácter helénico. En su polo opuesto está el «exceso», la hybris, la soberbia que niega la «humildad» que precisamente caracteriza el contenido de la otra de

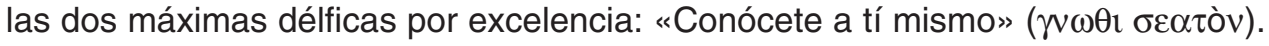
Aquello en que la sabiduría délfica invita a conocerse es precisamente la procedencia del humus («humildad»), que es característica de todo mortal. Esta mortalidad de lo terrestre es lo que se representa en toda la iconografía griega y latina referida al «Conócete a tí mismo». La humildad que pregona la procedencia a partir de la madre Tierra está así situada en el centro mismo del ideario délfico. Pero no sólo está en el centro de la propaganda délfica: Gaia está situada en el inicio mismo de la cronología relativa al santuario de Delfos.

\subsubsection{Gaia protómantis, primera ostentadora del oráculo}

En tiempos históricos es siempre Apolo quien dispensa el oráculo en Delfos. No faltan autores, como Fontenrose (1959), que conceden a Apolo la exclusividad en el dominio oracular de Delfos. En el ritual oracular délfico, pues, nada antes que Apolo. Pero en la historia de la religión griega no es así, al menos a nivel del mito. En la «Teogonía» de Hesíodo (vv. 463-65 y 624-28) es Gaia, la diosa Tierra, la que otorga a Cronos y a Zeus el favor de sus oráculos: Por un oráculo de Gaia sabe Cronos que es destino ser destronado por sus hijos. Por otro oráculo de Gaia sabe Zeus que, si libera de sus cadenas a los Cíclopes y a los Hecatonquiros, podrá vencer a su padre Cronos y ocupar su trono. Probablemente por esta íntima relación entre el poder mántico y la Tierra, sucede siempre que los oráculos son dispensados siempre en parajes tan salvajes que sacan fuera de sí e inspiran terror: o bien en cavernas (en el seno de Gaia) o bien en lugares en que algún elemento geológico parece ponernos en contacto con el interior de Gaia, como manantiales (en Delfos está la fuente Castalia), o emanaciones volcánicas. Esto es lo

11 La monografía más explícitamente dedicada al tema es la de J. DEFRADAS, Les thémes de la propagande delphique. Klincksieck. Paris, 1954. 
que cuenta Pausanias $(\mathrm{X}, 5,6)$, cuando habla de los pastores de Delfos que desde tiempos remotos caían en éxtasis divino (éntheol) bajo los efectos de vapores volcánicos (hypò toû atmoû) abundantes en la zona ${ }^{12}$.

Ya Miss Harrison en su «Themis» de 1911 (p.385) señalaba la importancia del hecho de que Ësquilo en el Prólogo de las Euménides colocaba a Gaia como la fundadora y primera dispensadora del oráculo de Delfos: «la protómantis Gaia» (AESCHYL. Eum. 1-2) ${ }^{13}$.

También Plutarco, probablemente siguiendo a Ésquilo, afirma que «a la Tierra dicen que perteneció el oráculo» (PLUT. Los oráculos de la Pitia, 402 D). El texto de Ésquilo coloca en línea sucesoria, tras Gaia, al frente del oráculo de Delfos a la diosa Themis (otro nombre de la Tierra), a la titánide Phoebe (la luna) y por último a Febo Apolo. Nada nos dicen los textos de cómo fue la sucesión de Gaia por Themis, ni la de ésta por Phoebe, divinidades que parecen quedar integradas en el reinado délfico de Gaia. Todo lo que sabemos del proceso sucesorio se reduce a la lucha que (según Eurípides) se produjo en Delfos a la llegada de Febo.

A partir de un texto de Eurípides en su tragedia de «Ifigenia en Táuride» poseemos un relato de la caída en manos del flechador Apolo del oráculo de la diosa Tierra, a la que representaba la serpiente Pitón. ${ }^{14}$ El dios de la luz, identificado con el sol, derrotó a la serpiente chthónica y tomó posesión del santuario délfico.

¿Qué sabemos del mito de Gaia en Delfos y de Pythón, la serpiente chtónica - aparte de su muerte a manos de Apolo-, y qué sabemos del rito oracular que se practicaba en Delfos antes de la llegada del dios Olímpico? No sabemos prácticamente nada. El relato de Eurípides podría llevarnos a pensar que con la derrota de la serpiente Pythón, todo el resto de la ideología propia de las divinidades terrestres fue expulsada de Delfos. Pero probablemente el mito de Eurípides no tiene sino el valor simbólico de representar la sucesión de Gaia por nuevas divinidades, de las que la última y definitiva fue Apolo.

Probablemente, a pesar del tono agónico de relato de Eurípides, la llegada de Apolo a Delfos no fue una verdadera ruptura ideológica, sino una mera reforma en el ritual oracular.

En ese sentido, Ésquilo en las «Euménides» tiene una forma de ver los hechos distinta de Eurípides. La línea sucesoria Gaia-Themis-Phoebe-Phoebo no repre-

12 Ver Thassilo de SCHEFFER, Mystères et oracles helléniques (traducción francesa del profesor André Sandt). Payot. Paris, 1943. Sin embargo, el mismo Thassilo de Scheffer, que alude al citado texto de Pausanias, unas líneas mas adelante (p.154) asegura que «hoy» en la zona de Delfos no hay rastro geológico de sima alguna ni de vapores volcánicos.

13 Véase J. DEFRADAS, Les thémes de la propagande delphique, pág. 23 ss.; M.P. NILSSON, «Das delphische Orakel in der neuesten Literatur», Hist., 7 (1958), 237 ss.; PARKE-WORMELL, The Delphic Oracle, I, págs. 3 ss.; en contra AMANDRY, Rev. Philol. 30 (1956), 269 ss.; FONTENROSE, The Delphic Oracle, págs. 1 ss.

14 «Enviada por la Tierra desde profundas cuevas, para ser la guardiana de tu oráculo (algo digno de estupor y miedo); pero tú, Febo, todavía un recién nacido, todavía recién salido de los brazos de tu madre Leto, mataste a la serpiente y te coronaste rey de Pytho, la tierra de la profecía» (EURIP. Iphig. in Taur., 1235-1257) 
senta para él sino un enriquecimiento de principios religiosos que se van entronizando —combatiéndose quizás, pero sin abatirse mutuamente- unos sobre otros. En palabras de la Pitia, los poderes que se suceden en Delfos no son (según Ésquilo) sustancialmente distintos: Themis se entroniza «en el oráculo de su madre» (v.3); la misma titánide Phoebe es también hija de la Tierra (XӨovos, v.6), «Chthon», otro sobrenombre de Gaia; y Phoebe, la luna, entrega el oráculo a su hermano Apolo Phoebo, el sol, como un mero regalo natalicio, "sin violencia de nadie», como ella misma lo había recibido (v.5). De esa manera, Ésquilo reivindica el permanente carácter chthónico del oráculo de Delfos, que perdura en la constante presencia de Themis, fundamento mismo de los oráculos, que seguían recibiendo el nombre de «órdenes de Themis» (thémistes, HARRISON 1911: 386 s.). Pero Apolo, no hay que olvidarlo, pronuncia el oráculo como intérprete de Zeus (Diòs prophétes , v.19), que representa al poder celeste de los dioses Olímpicos.

En el oráculo délfico, considerado ya a nivel sincrónico, se superponen los diferentes principios divinos, que, considerados a nivel diacrónico, se han ido sucediendo históricamente a la cabeza del santuario. Un elemento terrestre (simbolizado por Gaia y Themis), un elemento lunar, intermediario entre la tierra y el cielo (simbolizado por Phoebe) y un elemento celeste (simbolizado por Apolo, aunque sometido a Zeus) coexisten en cada época en Delfos y conforman entre todos la esencia del oráculo. ${ }^{15}$ Aunque a nivel mitológico — diacrónico- la serpiente Pitón ha sido vencida por Apolo, ella, y la ideología ctónica que subyace a su figura mítica, subsisten en el ideario propio del oráculo de Delfos. Significativamente la Pitia, en el prólogo de las «Euménides», honra en primer lugar (prôton), y antes que a nadie, a Gaia, la primera ostentadora del oráculo (protómantis): La primera en el orden diacrónico y la primera en el orden sincrónico.

De ello debemos deducir una consecuencia. En primer lugar, si , aplicando a Ésquilo y a Eurípides la misma metodología de Jean-Pierre Vernant con respecto a Hesíodo, damos al tradicional orden de sucesión del oráculo no sólo un valor diacrónico, sino también un inevitable valor sincrónico, hemos de adivinar la ideología chtónica subyaciendo a toda la ideología délfica. ${ }^{16} \mathrm{Y}$ en segundo lugar, no podemos menos que hacer constar el hecho de que la ideología ctónica está pre-

15 Aplicamos así un principio metodológico que Jane Ellen Harrison ha enunciado a propósito de Delfos: «In every rite and every mythological figure these elements must be reckoned with» (HARRISON 1911: 392393). Harrison se refiere aquí al elemento terrestre, lunar y celeste de los númenes griegos que ella considera no tanto elementos mitológicos cuanto «common human psychology» y «anthropology» (ibid., p. 393). En otro contexto distinto, el del Mito de las Razas, el antropólogo cultural francés Jean-Pierre Verrnant ha aplicado una metodología similar a la llamada ideología trifuncional indoeuropea de Georges Dumezil, que Vernant ha visto presente tanto a nivel diacrónico como a nivel sincrónico en el texto de Hesíodo. Ver J.-P.Vernant (1960 y 1966), Mito y pensamiento en la Grecia antigua, Ariel, Barcelona 1983, pp. 21-88).

${ }_{16}$ La continuidad de la ideología chthónica en Delfos se deduce del texto mismo de Ésquilo, si tenemos en cuenta que Themis, segunda en la lista tras Gaia, no es sino otro nombre de la Tierra; y que

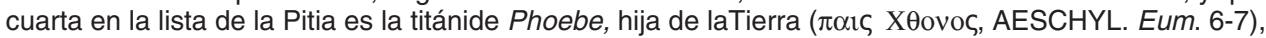
que entregó el oráculo sin violencia, y por tanto sin un cambio de ideología revolucionario, a Apolo, quien (ver ibid. 7-8) de ella tomó su nombre Febo (Phoibos). Pero los oráculos de Febo-Apolo siguen llamándose themistes como manifestación que siguen siendo de la voluntad de Themis-Gaia. Sobre la gradación -apadrinada por Ésquilo en Delfos-tierra (Gaia), luna (Phoebe, intermediaria entre la tierra y el sol), y sol (Phoebos), ver HARRISON 1911: 388 ss. 
sente en Delfos, desde el momento mismo de la creación del santuario, en todos y en cada uno de los oráculos que la Pitia emite. Lo que nos impone una conclusión ineludible: si Gaia, la madre Tierra, está por debajo de la inspiración de la Pitia, como diosa protómantis, la primera en el orden diacrónico, la primera en el orden sincrónico, ¿cómo, en un oráculo en que se menciona a la madre de Edipo, eludir en tal concepto de madre la presencia misma de la gran Madre Tierra? Ni la importancia de la madre Tierra en Delfos ni la inevitable ambigüedad esencial de la palabra de Apolo podían excusar que en el término madre se viera un signo ( $\sigma \eta \mu \alpha \iota v \varepsilon i v)$ de la presencia de Gaia en toda procreación humana, o, dicho de otra forma, de la mediación de toda esposa humana en el papel procreador de Gaia. De esa manera, Gaia se convierte en la cara oculta de la madre y toda madre biológica se identifica místicamente con Gaia. «El hombre y la mujer se unen no en calidad de "agentes" sino de instrumentos de la procreación... Lo que dice el conjunto de nuestros documentos es que el "agente"de este milagro es la Tierra". Así en Maria Daraki, ${ }^{17}$ que completa el aserto con una cita de Platón: «No es la Tierra quien imita a la mujer en el embarazo y el parto, sino la mujer quien imita a la Tierra» (PLAT. Menexenus, 237 e y 238 a). Referido al oráculo de Apolo, eso significa que por una necesidad teológica - acorde con la ideología délfica- Edipo estaba destinado a acostarse con Gaia, la madre Tierra, su madre, a través de quienquiera que fuera su esposa y la madre de sus hijos biológicos.

En el plano sincrónico el oráculo era dispensado por una mujer, la Pitia o Pitonisa, sentada sobre una sima en la Tierra. La Pitia no sólo era inspirada por las hojas de laurel que masticaba, sino que era colocada en trance por los vapores mefíticos que emanaban de la sima de la tierra sobre la que se sentaba. ${ }^{18}$ Entramos, así, en el terreno del rito. ¿Cuál era la presencia de la Tierra en el santuario y en el templo mismo de Delfos?

\subsubsection{Templo de Gea en Delfos: el omphalós}

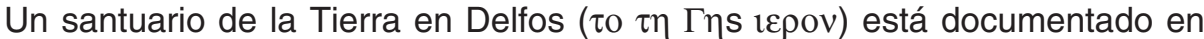
PLUT. Moralia VI: Los oráculos de la Pitia, 402 C y D. El hecho de que el omphalós estuviera situado en el templo de Apolo, como testimonia Ésquilo (Eum. 39-40), parece implicar que el templo de Gea al que se refiere Plutarco no es otro que el

17 DARAKI, Maria. Dioniso y la diosa Tierra. Abada, Madrid 2005, p. 165.

18 «That oracle was actually delivered by a woman seated over a cleft in the Earth and inspired not only by the laurel she chewed but by mephitic vapours that rose from the earth" (HARRISON 1911:386). Sobre el origen del oráculo se cuenta una anécdota transmitida por Diódoro de Sicilia (XVI,26): «Al parecer, el oráculo fue descubierto por un cabrero que recorría la zona de Delfos. Algunas de sus cabras comenzaban a comportarse de un modo extraño cuando se acercaban a una grieta sobre el suelo, balando y brincando de forma inusual. El pastor se acercó al agujero y súbitamente experimentó la facultad de ver el futuro, pues de las profundidades surgían ciertos vapores misteriosos. Las gentes, desde entonces, aprovecharon las propiedades del lugar y se supone que, mucho después, cuando se edificó el templo de Apolo en Delfos en aquel lugar, era sobre aquella grieta donde se situaba la Pitia en su trípode para emitir sus profecías» (David HERNÁNDEZ DE LA FUENTE, Oráculos griegos, Alianza ed. Madrid 2008, pp. 38-39). 
templo de Apolo en época clásica, que probablemente fue construido sobre un antiguo templo dedicado a la Madre Tierra. La arqueología reciente confirma la existencia de ese templo de Gaia: «Es muy importante que haya sido encontrado bajo bloques de roca prehistórica - el antiguo templo de Gaia, descubrrimiento que confirma lo que sabemos del culto de la Tierra». ${ }^{19}$

Entre los restos de piedra que se conservan en los terrenos del santuario de Delfos hay una piedra blanca en forma de cono un poco menos alta que un hombre. Es el llamado omphalós, «ombligo». Visto en sí mismo el término sugiere un punto biológico de la madre (Tierra) asociado a la procreación, aunque el lugar mismo del que salen los hijos es el útero materno a través de la vagina. La Pitia, en el prólogo de las «Euménides» de Ésquilo, ubica el omphalós en el fondo de su propio templo (mychón, v.39-40), es decir, el templo que en la época clásica de Atenas, el tiempo de Ésquilo, de Sófocles y de Eurípides, y actualmente, se reconoce como el templo de Apolo.

La brillante antropóloga del mundo clásico Jane Harrison, a principios del siglo pasado, daba a entender que poco o nada se puede deducir del nombre mismo acerca de lo que el «omphalós» délfico significaba. ${ }^{20}$ ¿Es así?

Hay que partir de que, si el nombre mismo (omphalòs, «cordón umbilical») sugiere el lugar por el que el recién nacido —y antes su feto- se une al útero de la madre, puede ser entendido fácilmente como una metáfora de algo que ocupa el centro, igual que el ombligo es aproximadamente el centro del cuerpo humano. Hay abundantes testimonios de que así sucedió en Delfos, al menos en una época ya histórica. Pausanias $(X, 16,2)$ resume el testimonio de varios siglos considerando el omphalós como verdadero centro del mundo. Pero muchos autores objetan que no debió ser así al principio, que eso sólo sucedió en época relativamente tardía. Y que además pronto se deshizo el malentendido. Ya Epiménides de Creta, hacia el año 500 a.C., que tenía la experiencia de haber visto un omphalós que existía en su isla, como en otros lugares que tenían la pretensión de ser el centro del mundo, niega que el omphalós de Delfos sea centro de nada:

«No hubo en verdad un ombligo en medio de la tierra ( $\gamma \alpha \iota \eta)$ ni del mar; y, si alguno hay, es claro para los dioses, pero no para los mortales». ${ }^{21}$

El arqueólogo romano Varrón (De lingua latina, VII,17) en el siglo I a.C. asiente a lo que dice Epiménides, añadiendo que el ombligo ni siquiera es el centro del cuerpo humano. Queda así desmentida la famosa anécdota de las dos águilas que Zeus soltó en los extremos opuesto del mundo y que volando siempre en la misma dirección y a la misma velocidad acabaron por encontrarse justamente sobre la

19 «ll nous imperte beaucoup que I'ait retrouvé, sous des blocs de roche préhistorique, I ancien sanctuaire de Gaia, découverte que confirme ce que nous savons de ce culte de la Terre» (SCHEFFEER 1943: 166). 396.

20 «The name omphalos is little or no help» (J. HARRISON. Themis. Merlin Press, London 1911, p.

21 Epiménides en PLUT. def.orac. 1, 409 F (DK 3 B 11). 
montaña del Parnaso en Delfos. Una representación en relieve de ambas águilas aparece a veces esculpida a los lados del omphalós.

La arqueología -eso sí tardía- del enclave de Delfos nos ha dotado de algunos ejemplares arquitectónicos del omphalós que deberían ilustrarnos sobre su esencia propia. Hay diversas teorías sobre su función. Con otros muchos autores Miss Harrison concluye que se trata de una tumba. Su forma de protuberancia cónica no sería sino un recuerdo de los tiempos en que los enterramientos se cubrían de un montón de tierra. Ya Varrón, acompañado por otros autores antiguos, había dicho que el omphalós es la tumba de la serpiente Pythón. ${ }^{22}$ Una pintura pompeyana muestra el omphalós rodeado por el cadáver de la serpiente recién matada por Apolo. Pero, siendo así, hemos de preguntarnos si la realidad significada por el omphalós - que no pasaría de tener mero contenido mítico- vuelve a remitirnos a la madre Tierra. En la pintura pompeyana la serpiente Pitón no está bajo el omphalós - como la función de una tumba exige-, sino que está sobre el omphalós o meramente en contacto con él. Podría ser algo más que una forma de hacer visible pictóricamente el contenido de la tumba. Python yace junto al ombligo de la Tierra porque los muertos en toda la teología funeraria griega - como antes, al menos, en la teología egipcia - regresan al seno de la diosa madre. ${ }^{23} A$ fortiori regresa junto a su madre en la hora de la muerte Pythón, a la que su naturaleza serpentina de habitante de las oquedades del subsuelo concede un estatuto especial de hija primigenia de la Madre Tierra.

Pero debemos situarnos en los orígenes del concepto. Antes de todo sentido metafórico, el término omphalós remite a la anatomía del aparato reproductor y desde el ombligo, a través del cordón umbilical (omphalós significa "cordón umbilical» a la vez que ombligo) se accede al útero materno. Ya el antiguo y famoso texto de Píndaro, aunque se refiere a la posición intermedia del omphalós, no deja de asociarlo con la madre:

«Le llegó a su corazón sagaz un escalofriante vaticinio (manteuma), proferido en el central ombligo (méson omphalòn) de la madre ( $\mu \alpha \tau \varepsilon \rho o)$ (tierra, $\gamma \alpha \iota \alpha)^{24}{ }^{24}$.

Quizás el escepticismo de Epiménides acerca de la centralidad el ombligo de Delfos haya que entenderlo como una reivindicación del origen cretense del omphalós. No faltan autores modernos que suponen el origen cretense del

22 Sed terrae medium non hoc ... quod Graeci vocant omphalon, quem Pythonos aiunt tumulum (VA-

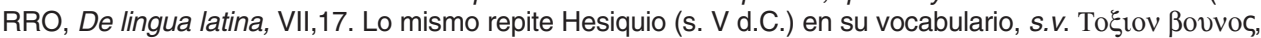
«tumba del arquero».

${ }^{23}$ Así lo testimonia Henry Frankfort, quien afirma que la tumba egipcia, el sarcófago, suele contener pintada en su interior una representación de Nut, la diosa madre, que el mito egipcio identifica con el cielo: «El ataúd —con un simbolismo que conoce bien el psicoanálisis- se convertía en la diosa madre Nut, que engendra al sol cada mañana, y a las estrellas cada noche» (FRANKFORT, H. Reyes y Dioses. Alianza ed., Madrid 1983, p. 29; ver también pp. 196-200). Sobre rituales de nacimiento y fertilidad, por un lado, y muerte por otro lado, en el santuario de Eleusis, dedicado a Deméter, la diosa madre, ver Maria DARAKI, Dioniso y la diosa Tierra, Abada ed. Madrid 2005, p. 154.

24 PIND. Pyth. IV, 73-74. En la Pyth. XI, 10, Píndaro ignora la posición central del omphalós, pero lo asocia exclusivamente con la tierra ( $(\eta \varsigma, \mu \phi \alpha \lambda o v)$. 
omphalos. ${ }^{25}$ Según la llamada Suite Pítica del Himno Homérico a Apolo, de Creta habían sido importados los sacerdotes de Apolo, cuando éste tomó posesión del oráculo. ${ }^{26}$ La propaganda apolínea de Delfos acaparó para sí el omphalós, de la misma manera que La Suite Pítica del himno a Apolo acaparó la creación del sacerdocio cretense en Delfos. ¿Pero no estarían tales sacerdotes cretenses en el origen mismo del santuario? Cretense era para los griegos la cuna del culto a la gran diosa Madre. ¿No es inevitable, pues, buscar el origen del ombligo en la anatomía misma de la madre? La relación del ombligo con el seno de la Madre Tierra se hace aún más patente si se presta la atención debida al término mismo que designa al santuario de Delfos. Al margen de la asociación coyuntural de Apolo con el delfín, resulta un hecho incontestable la relación etimológica de Delphoi, «Delfos», con la palabra griega delphys $(\delta \varepsilon \lambda-$ $\phi v s)$, antigua denominación en lengua griega del «útero materno», luego llamado metrá. Es posible que la aproximación etimológica estuviera basada en la conformación geológica misma del territorio montañoso del santuario, plagado de simas y de oquedades. ${ }^{27}$

En Delfos - sobre todo si se confirma la emanación de vapores mefíticos por alguna de las simas del terreno- se respiraba más que en cualquier otro lugar de Grecia el contacto con el interior mismo de Gaia. Incluso las guías más modernas del santuario de Delfos destacan la naturaleza del terreno, sujeto a frecuentes movimientos sísmicos. También el término griego Pytho, nombre del lugar donde la serpiente Pitón cayó muerta por las flechas de Apolo, sugiere olores sulfúricos, «olor a podrido», que podrían emanar del interior de la tierra. Una anécdota mitológica sugería que la serpiente ctónica, muerta, despedía un olor putrefacto que dio origen al nombre: ${ }^{28}$ Es posible que en algún momento histórico o prehistórico se pensara que el cadáver de la serpiente matada por Apolo estaba enterrada en una de las simas de la tierra délfica que emitían vapores mefíticos.

Sumando todos estos factores, se puede concluir que la creencia griega de que todos los hombres nacían del interior de la Madre Tierra se concretaba en Delfos, donde se creía que estaba el seno de Gaia, y por donde se creía acceder a su útero materno. ¿Por qué entre tantos factores predominó la idea del omphalós, única realidad de la que nos ha quedado resto arqueológico? Probablemente porque al mezclarse la idea del cordón umbilical con la del ombligo, y al fi-

25 «On avaiet pensé que le fameux E gravé sur I'omphalos comme sur le temple d'Apollon serait un caractère minoen: importé de Crète avec I'omphalos comme signe de la divinité féminine primitive, il aurait eté accaparé par le nouveau dieu» (Jean DEFRADAS, Les thèmes de la propagande delphique. Klincksieck, Paris, 1954, p.104; Defradas cita a propósito del dato a W.N. Bates, AJA, XXIX, 1925, p. 103, n. 2).

26 HIMNO HOMÉRICO II (a Apollo Pyth.), vv. 389-544.

27 Ver Pierre CHANTRAINE, Dictionnaire étymologique de la langue grecque, s.v. $\Delta \varepsilon \lambda \phi o t$. A propósito del término griego adelphós, »hermano uterino», Chantraine cita a Hesiquio (s.V d.C.), que explica el antiguo significado de la palabra delphys:»delphys, o sea, el útero materno».

28 HIMNO HOMÉRICO II (a Apolo Pyth.), vv. 363-374. Sobre Pitón (gr. Pythôn), el nombre mismo de la Serpiente, el himno no dice nada, sino que se limita a explicar el nombre del lugar, (Pythò, v. 372) de donde el nombre de Apolo «Pítico» (Pýthion, v. 373). Eso parece indicar que etimológicamente la putrefacción del lugar precede a la de la Serpiente misma. 
jarse ésta en su aspecto geográfico -más traducible en términos arquitectónicos, como la piedra que constituye el omphalós, el mojón que señala el centro geográfico del mundo-, el ombligo sobreseyó y sustituyó a otras partes menos representables del aparato reproductor de la Madre Tierra.

De esa manera quedaba invertida la semántica original del término omphalós, que en el sentido de cordón umbilical no se refería primigeniamente a un punto biológico de la madre, sino del hijo, de todos sus hijos: el omphalós pasó de ser un lugar de cada hombre a ser el ombligo de la Madre misma: el ombligo de todos los ombligos y el centro mismo de superficie de la tierra. Se culmina así un proceso de transformación metonímica. Resumiendo, en la madre tierra ómphalos se corresponde más bien con aquel punto de la placenta por el que el cordón umbilical de los nacidos se comunica con el útero materno, con el centro aproximado de la Madre Tierra.

En el segundo nivel temporal de Delfos -transición que probablemente se completa a lo largo del siglo VII a.C.- la doctrina ctónica de Gea viene sustituida por el oráculo de Apolo solar, que representa el dominio de los nuevos dioses Olímpicos. En este contexto se hace cada vez más superfluo el tema del vientre de Gea. El ombligo podría pasar a identificarse incluso con el del niño Zeus o con la piedra que lo sustrajo a su devoración por Cronos-Saturno. Pero la doctrina oficial de Delfos no renuncia al tema de la centralidad del santuario délfico y, por lo tanto, al motivo de la centralidad del «omphalós».

\subsubsection{Lo ctónico en el ideario délfico: ¿preponderancia de la madre o del padre?}

¿Existe una ideología délfica verificable? Es sobradamente conocido el título de la obra de J. Defradas sobre los temas de la «Propaganda Délfica». Un ideario de Delfos habría que deducirlo indirectamente a partir del mismo ritual délfico, de las inscripciones que los peregrinos leían en los templos, de los himnos y demás literatura délfica (algunos de los cuales - como el famoso Himno a Apolo- están recogidos en los llamados «Himnos Homéricos») y, sobre todo, de las letras mismas, verso o prosa, en que se expresaban los oráculos. Los sacerdotes encargados de reducir a contenido semántico los inconexos sonidos emitidos por la Pitia, dejaban sin duda que su propia ideología délfica empapara el contenido de su composición literaria. Pero nada más. El sacerdocio délfico carecía de cualquier estatuto jurídico que lo facultara para impartir doctrina o algo parecido a contenidos dogmáticos. ${ }^{29}$

Sin embargo, algunos temas son recurrentes en la literatura délfica: Tal es el caso de la preponderancia de la madre sobre el padre.

29 «Il n existait ní écrits canoniques, ni prescriptions ayant partout force de loi» (SCHEFFER 1943:151) 
Tras el prólogo en que Ésquilo, al inicio de las «Euménides», enuncia la igualdad (isonomía) de divinidades antiguas, como Gaya, Themis y Phoebe, y nuevas, como Apolo, se pasa al conflicto generado por el asesinato de Clitemnestra a manos de su hijo Orestes, y por el subsiguiente enfrentamiento de Apolo con las Erynies. ${ }^{30}$ Orestes ha acudido a refugiarse bajo la sombra de Apolo en Delfos, huyendo de las «Furias», las Erynies, hijas de Gaia, que pretenden cumplir con su función de castigar los crímenes de parricidio: Orestes ha matado a su madre Clitemnestra, para vengar la muerte de su padre Agamenón asesinado por su esposa Clitemnestra y el pretendiente Egisto. El ombligo de Ge ( $\gamma \alpha s$ o $\mu \phi \alpha \lambda o ́ v$, Eum. 166; ver 40 s), o sea de Gaia, ha sido «manchado de sangre» por Orestes. Las Erynies defienden el orden ctónico de Gaya, propiciando el castigo del matricida Orestes; Apolo defiende al hijo matricida de Agamenón, reivindicando así la superioridad del varón y del orden Olímpico.

Las Furias no discuten que deba ser castigada una esposa, Clitemnestra, que ha matado a su marido, Agamenón (si ello es así, y no un recurso de la versión délfica de la «Orestia», pues en Homero ha sido exclusivamente el amante Egisto quien ha asesinado al marido de su amante Clitemnestra (HOM. Od. XI, 409 ss.); Clitemnestra asesina personalmente a Casandra y es, eso sí, cómplice de Egisto, «tramando la muerte» de Agamenón (ibid. XI, 422 ss.). La que podríamos llamar Orestia délfica - frente a la homérica - puede ser datada dieciséis años antes de la trilogía de Ésquilo, cuando Píndaro en la Pítica XI hace morir a Agamenón «por las manos violentas de Clitemnestra» (Pyth. XI,18). El poeta beocio se pregunta si fue la venganza por la muerte de Ifigenia a manos de Agamenón o si fueron las ansias por defender su lecho adulterino lo que impelió a Clitemnestra a manchar sus manos de sangre. Es obvio que Píndaro sigue una tradición diferente a la homérica: llama «laconio» (es decir, espartano, o, lo que es lo mismo, dorio) a Orestes (ibid. v.16) y sitúa el palacio de Agamenón «en la ilustre Amiclas» (v.32) al sur de Esparta, en vez de en la homérica Micenas. Ésquilo mantiene probablemente - la letra del proespartano Píndaro. Pero, en todo caso, las Erinías arguyen en las «Euménides» que a ellas no les compete castigar un crimen que no ha sido parricidio, pues — como es natural dentro del matrimonio- Agamenón no es de la misma sangre que su esposa Clitemnestra (AESCHYL. Eum. 211 s. y 605).

De esta manera, el crimen contra la madre se ha convertido en el asunto central de la Orestia y el tema de las «Euménides» de Ésquilo. No Egisto, sino la misma Clitemnestra fue quien «a su marido golpe mortal le asesta» (kóptei ... ándra, Eum. 635). Clitemnestra ha pasado a ser el personaje principal: Sobre ella descarga Orestes el peso de su venganza. Se observa en ello un desplazamiento de la ideología délfica desde el ideario preferente de la intocable madre (Gaia) a una justificación de la preponderancia del principio paterno

30 Miss Harrison ve en el Prólogo de las Euménides un planteamiento de lo que va a ser leit-motiv de la obra (y de toda la trilogía de Orestes: «the conflict of the two social orders of which these daimones (Erinyes) and theoi (Apollo y Atenea, y Zeus por encima de ellos) are in part the projections -matriarchy or, as it is better called, the matrilinear system and patriarchy (HARRISON 1911:386). 
(Apolo). En el juicio, que se celebra en Atenas por deferencia de Apolo (y naturalmente del ateniense Ésquilo) con la diosa Atenea, presente en el templo y sobre todo en el Tesoro de los Atenienses de Delfos), ${ }^{31}$ la argumentación se decanta a favor del padre: Apolo, que actúa como testigo de cargo de Orestes a quien había incitado al matricidio- justifica el crimen de Orestes apelando a la primacía del padre sobre la madre: «La que se llama madre no es la progenitora del hijo (téknou tokeús), sino la nutricia (trophós) del germen recién sembrado. Engendrador es (tíktei) quien la ha fecundado» (AESCHYL. Eum. 658 s.). Quizás en el argumento de Apolo tuviera algún peso la excesiva relevancia que una nueva genética ateniense - hasta entonces anulada por la labor procreadora del útero femenino- atribuyera en la concepción al espermatozoide masculino. Pero el error genético no sería flagrante, si a continuación Apolo no atribuyera al germen masculino una importancia exclusiva interpretando mal el nacimiento de Atenea: «La prueba te daré de cuanto digo: puede existir un padre sin que la madre exista. Y muy cerca tenemos un testigo, la propia hija de Zeus, rey del Olimpo. No fue gestada en las tinieblas de una entraña materna, y, sin embargo, ¿qué diosa lograría dar a luz un retoño semejante?» (ibid. 662-666). En efecto, Atenea nació directamente de la cabeza de Zeus. Y la propia diosa, varios versos más adelante asiente al peregrino argumento de Apolo: «No he tenido una madre que me diera a luz, y en todo, con todas las fuerzas de mi alma, por el varón me inclino, salvo en tomar esposo: soy sin reserva alguna del bando de mi padre» (ibid. 736-740).

El ataque frontal a la preponderancia de la Madre Tierra en la procreación es aquí manifiesto. En otros ambientes y en otros textos (ver SOPHOCLES, Oed.Bas. passim) la preeminencia de la Tierra en la labor procreadora es reconocida sin vacilación, cuando se hace a la madre biológica intermediaria de Gaia y al varón mero labrador del surco materno. Pero aquí Gaia es ninguneada, cuando se proclama la no necesidad del útero materno, claramente comparado con el tenebroso seno de la Madre Tierra (en skótoisi nedýos, v.665). Pero tal argumentación no podía convencer plenamente a Ésquilo. A la total nulidad del argumento contra la madre - «engendrador (exclusivo) es quien la ha fecundado" (Eum. 660), que valorado desde el lado biológico es simplemente erróneo, hay que añadir la inexactitud del punto de vista mitológico que reclama Apolo: El nacimiento de Atenea no prueba el carácter superfluo de la intervención femenina en la procreación, pues Atenea había sido concebida por la titánide Metis antes de ser devorada ya embarazada por Zeus. Probablemente en el mito primigenio Atenea carecía precisamente de padre (véase el mito órfico de Phanes), lo que indujo a los redactores de la mitología Olímpica a afirmar hiperbólicamente la paternidad de Zeus y combatir así la pretensión de los partidarios de la teología ctónica de haber nacido asexuadamente de la madre

31 Ya en el Prólogo de las «Euménides» Apolo hace su marcha triunfal —aunque pacífica- desde Delos a Delfos a través de Atenas, donde «los hijos de Hefesto» (los atenienses) lo acogen y le hacen escolta construyendo para él el camino que conduce a través de parajes aún salvajes hasta el santuario de Pytho (Eum. 12-14). 
Tierra. ${ }^{32}$ Atenea preside el tribunal que debe sentenciar la culpabilidad o la inocencia de Orestes. Cuando le llega el momento de pronunciarse, la diosa de Atenas añade su voto al de Apolo y los que han votado a favor de Orestes. Pero la afinidad de los autóctonos atenienses con la Madre Tierra se muestra en el empate mismo que Atenea dirime: Sin su voto a favor de Orestes -y del padre - hubieran salido vencedoras la Erynies y la labor procreadora de Gaia.

Es evidente que en toda la historia mítica de la dinastía micénica que aquí estamos considerando luchan dos principios fundamentales: un principio primitivo-délfico (Ge como símbolo de la maternidad y de todas las madres y mujeres) y un principio dórico, o mejor, Olímpico (para no confundir dorios y micénicos): la preeminencia del varón, del padre, de Agamenón, o mejor dicho, de la sangre de Agamenón, vengada por su hijo Orestes.

Lo mismo sucede en parte de la historia mítica de la dinastía tebana, en la que Layo y Edipo sufren las consecuencias de una crisis antropológica - una crisis de civilización- que pone en conflicto las relaciones de parentesco y, más en concreto, el concepto mismo de paternidad. Layo muere a manos de su hijo, Edipo se autocastiga con la ceguera por causa de unos hijos incestuosamente procreados. La madre (quizá la madre biológica, Yocasta; quizá la madre Tierra) no puede ejercer una maternidad que no sea conflictiva, que no choque con el nuevo principio de paternidad. Es fácil intuir aquí un tema matriarcal, propio del ideario délfico más primitivo, autóctono, simbolizado por la madre Tierra, y un tema patriarcal, propio del ideario délfico más reciente, simbolizado por el advenedizo Apolo y la ideología micénico-dórica (indoeuropea). ${ }^{33}$

\subsection{La madre tierra en el oráculo histórico/mítico}

Fontenrose, en su obra «The Delfic Oracle», afirma que el oráculo es ambiguo en los casos en que se refieren sentencias mitológicas de la Pitia; pero es unívoco y claro en todos los casos de sentencias históricas que se conservan. El principio

32 Sobre el sentido de los «embarazos» masculinos de Zeus y sobre la «virginidad» de Atenea puede consultarse Georges DEVEREUX. Femme et Mythe. Paris, Flammarion, 1982, cap. IV y XI. La religiosidad ctónica niega la preeminencia del padre que afirma la religión Olímpica. Pero ello no implica necesariamente que Ésquilo haya concebido las «Euménides» como una disquisición antropológica acerca del choque entre una sociedad matriarcal simbolizada por la Erinías y una sociedad patriarcal preconizada por Apolo: «It is hard to see haw Aeschylus could have thought in these terms: Matriarcal societies had long been extinct even if they had once existed» (Brooks OTIS. Cosmos and Tragedy. An Essay on the meaning of Aeschylus. The University of Carolina Press. Chapel Hill, 1981, p. 101).

33 «La historia mítica de la dinastía tebana se interroga fundamentalmente por las estructuras de parentesco patrilineal. Este cuestionarse podemos nosotros -irremediablemente historicistas- comprenderlo como producto del choque de una sociedad pregriega matrilineal con la nueva sociedad patriarcal traída por los indoeuropeos, en la que el linaje se establece por línea de varón y dentro de cuyo marco no se logra asignar a la mujer (Yocasta) un lugar adecuado ni como esposa ni como madre» (RUIPÉREZ, Martín S. El mito de Edipo. Lingüistica, psicoanálisis y floklore. Madrid. Alianza, 2006, p. 46. Ver también la fuente a la que se remite el texto recién citado: T.S. TURNER apud Vernant 1981. 
no puede ser generalizado: En ambos casos, el del oráculo histórico y el del oráculo legendario, hay respuestas que se escapan a la regla.

El dato de Fontenrose se puede combinar con la descripción que hace Plutarco de la evolución histórica del oráculo, que oscila entre la primitiva y casi impenetrable oscuridad, cuando el oráculo era en verso $-\mathrm{y}$ reflejaba mejor la irracionalidad del elemento terrestre de Delfos- y la progresiva clarificación de las palabras de la medium de Apolo, cuando el oráculo se hace en prosa y responde más directamente a la claridad solar de lo apolíneo.

En su libro sobre el oráculo délfico (1978) Fontenrose reduce la ambigüedad de los oráculos al ámbito de las respuestas legendarias, que son en concreto las que documenta la literatura clásica —como el «Edipo» de Sófocles— referidas siempre a personajes de la edad oscura, legendaria, de Grecia. El devoto que consulta a Apolo, como Edipo, se siente decepcionado y descorazonado con las respuestas del oráculo, «porque son oscuras o porque las palabras no son empleadas en su sentido ordinario". ${ }^{34}$ Profecías de este tipo son abundantes en los cuentos de la literatura universal y en la leyenda de muchos pueblos. Muy a menudo los oráculos equivalen por su propia naturaleza a verdaderas adivinanzas o enigmas. Este principio se cumple en el mito de Edipo, que los comentaristas en general, y Fontenrose en particular, están de acuerdo en calificar formalmente como un verdadero cuento popular folktale- al menos en sus estratos más antiguos.

Por otra parte, Fontenrose argumenta repetidamente — teniendo en cuenta lo que se dice de Edipo en la Odisea de Homero (canto XI) - que la predicción sobre el destino de Edipo en la versión primitiva no era consecuencia de un oráculo délfico. Quizás era entonces más bien, una forma de adivinanza popular, como el mismo enigma de la Esfinge, que ocupa un lugar central en el drama de Sófocles. Esto acentuaría aún más la ambigüedad del «dicho» (tuviera el carácter literario que sea) relativo a la futura relación de Edipo con su madre y con su padre. ¿Debía, pues, ser entendido al pie de la letra el oráculo que Layo y Edipo recibieron en Delfos en sucesivos estratos de la leyenda?

En los oráculos que no son directos (es decir, en los que el contenido del oráculo no se corresponde con los hechos, sino que debe ser objeto de interpretación simbólica), las reglas hermenéuticas son (?) las mismas que Artemidoro enuncia para los sueños:

1) «En última instancia la onirocrítica no es otra cosa que una relación entre elementos analógicos» (ARTEM. II 25).

2) Todo se reduce a la lógica mental de la asociación»: «asociación de ideas ... mediante la aplicación de criterios tales como la continuidad, la inversión, la antítesis, la contigüidad, la semejanza... Resultan particularmente interesantes aquellos mecanismos que son de naturaleza verbal... polisemias,

34 «because they are obscure, or because words are not employed in their ordinary meaning» (FONTENROSE, op. cit. p. 58) 
homofonías...» (RUIZ GARCÍA, Elisa. Introdución traducción y notas. Artemidoro: interpretación de los sueños. Madrid. Gredos, 1989, p. 39).

Oráculos concretos confirman la identidad en Delfos entre madre y Tierra.

Hay primeramente un tipo de oráculo en que madre predica literalmente por la madre personal. Veamos un ejemplo muy destacado (Defradas 1954: p.184):

«Alcmeón, hijo de Anfiarao, rey de Argos, recibe de su padre el encargo de vengarlo de Erifila, su esposa y madre de Alcmeon. Ésta, tentada por Polinices, hijo de Edipo, con la oferta a cambio del precioso collar de bodas de Harmonía, había empujado a Anfiarao a participar en la expedición de los Siete contra Tebas, aunque ella y él sabían - a través del arte adivinatoria de Anfiarao- que iba a resultarle fatídica, como así fue. Alcmeón aún no había podido ejecutar la venganza, cuando dio comienzo la subsiguiente expedición de los Epígonos contra Tebas, de los que él fue nombrado jefe supremo. Ante la duda, Alcmeón fue a consultar el oráculo de Delfos, que le ordenó «matar a su madre y participar en la expedición» (DIOD: IV, 66). Lógicamente Alcmeón entendió al pie de la letra el término «madre» y, aunque Diódoro nada dice al respecto, se entiende que asesinó a su madre biológica y esposa de Anfiarao, Erífila, pues a continuación no dejó de cumplir la segunda parte del oráculo y acudió a Tebas de donde regresaría esta vez victorioso al frente de los Epígonos.

Hay también un tipo de oráculo en que el término madre predica unívocamente no por la madre biológica, sino por la madre Tierra, como apoya el mismo contexto de la pregunta del consultante y de la respuesta del oráculo. Es el caso de la consulta a cerca de la tierra en que nació Homero. El mismo Homero formula la pregunta -dentro de un contexto seguramente legendario- en dos variantes: «¿Quiénes fueron mis padres y de dónde? » (así, pero en estilo indirecto, en un pasaje del Pseudo-Plutarco $<l, 4>$ ), «¿Cuál es mi patria?» (así en un pasaje del Certamen de Homero y Hesíodo $<$ HES. Cert. 32-35>, en el que quien pregunta en estilo indirecto es el emperador Adriano de visita a Delfos). Es evidente que la primera parte de la primera variante recuerda a la pregunta que en la tragedia de Sófocles acudió Edipo a hacer en Delfos. La respuesta, completa y en verso, que Homero recibió del oráculo es relatada por Pausanias, a propósito de una estatua de bronce que él asegura haber visto en Delfos en la que se puede leer la respuesta que él recibió del oráculo:

«Feliz y desgraciado, porque has nacido para lo bueno (su poesía) y lo malo (su ceguera).

Buscas una patria ( $\pi \alpha \tau \rho i ́ \delta \alpha \delta ' \zeta \eta \alpha \mathrm{l})$.

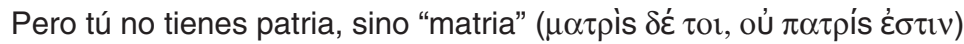

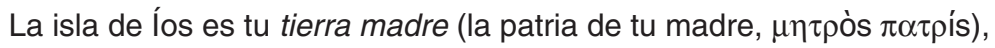

la que te recibirá (en su seno) cuando mueras» (PAUS. X, 24,2). ${ }^{35}$

35 Una versión de los dos primeros versos reaparece en PSEUDO-PLUT. I, 4. En cualquier caso, es claro que la madre que ha de acoger (en su seno) a Homero a la hora de la muerte no es precisamente la madre personal, sino necesariamente la tierra, a la cual se tiene que referir, como antecedente del relativo, la difícil expresión griega "patria de tu madre» ( $\mu \eta \tau \rho o ̀ \varsigma ~ \pi \alpha \tau \rho i \varsigma)$. Tal madre, en consecuencia, no tiene nada que ver con la madre biológica, sino que predica clara y unívocamente por la madre Tierra. 
El texto necesita pocos comentarios. Pero merece la pena recalcar lo que en este oráculo consideramos centro de la propaganda délfica: No busques tus padres carnales, sobre todo tu padre (al contrario que Edipo, quien acudió a Delfos queriendo asegurarse la filiación de Pólibo y el reino de Corinto), no busques la patria, la tierra de tu padre, sino la Madre Tierra, que es la madre de todos (los griegos) por encima de toda paternidad tribal. $Y$ te interesa sobre todo tu madre, porque eres mortal («gnothi seauton») y es precisamente la madre tierra la que te ha de recibir en su seno (no tu padre) y sola ella la que te ha de asegurar que (como Perséfone y la espiga de Eleusis) has de volver a nacer. Y esa tierra que te ha de recibir en su seno no es concreta ni necesariamente ĺos, sino la tierra Madre. Tema que veremos repetido cuando Edipo en Colono - despreciando a su patria Tebas- se sumerja en el seno de la tierra al final de la tragedia de Sófocles, a cuya luz habrá que entender el oráculo y todo el tema del «Edipo Rey» (Oedipus Tyrannos). ${ }^{36}$

Hay también oráculos concretos que prueben la ambivalencia característica. de las palabras de la Pitia. Muchos ejemplos de oráculos délficos prueban que el oráculo acerca de la madre de Edipo en Delfos pudo haber sido entendido de otra manera. Veamos oráculos donde, en evidente caso de analogía, la palabra «madre» predica por la madre Tierra: ${ }^{37} \mathrm{o}$, inversamente, la tierra predica por la madre:

Los Heráclidas atienden a un oráculo que les avisa de esperar a la tercera «cosecha» antes de invadir el Peloponeso. Ellos interpretan mal el oráculo al entenderlo literalmente y no identificar «cosecha» con generación humana (cf. Fontenrose 1978: L61, p. 378).

Deucalión y Pirra son instruidos por el oráculo para que, terminado el diluvio, repueblen de humanos la tierra sembrando el suelo con los «huesos de su madre», lo que ellos entienden rectamente arrojando al suelo rocas (Fontenrose 1978: L118, p. 395s.).

\subsection{Madre Tierra en el sueño oracular (el sueño de Yocasta en el «Edipo Rey»)}

El tema del sueño, o más en concreto el de la interpretación o adivinación del sentido de los sueños, no puede separarse del de los oráculos. Era opinión común

${ }^{36}$ Ver SOPHOCL. Oed.Col. El tema de la irrupción final de Edipo en el seno de Gea será desarrollado más en detalle en un futuro artículo del mismo autor.

37 Fontenrose cifra la ambigüedad del oráculo en dos recursos literarios: homonimia, equivocidad en el orden de palabras (aio te, Aeacida, Romanos vincere) y, sobre todo, metonimia. Ejemplos de homonimia, analogía, etc..: a) mulo (Ciro) : Creso no debía temer, «mientras un mulo no gobernase a los medos» (HERODOTO). Ciro podía ser considerado un híbrido, pues había nacido de una princesa meda (Parisatis?) y de un oficial persa. b) ...., y sobre todo, Tierra= madre (que es la ambigüedad analógica inversa del caso de Edipo en Delfos, donde madre puede, al menos por hipótesis, predicar por Tierra. 
entre los antiguos que los mismos sueños tenían un valor oracular, opinión que confluye en Plutarco al final del mundo antiguo (PLUT, La desaparición de los oráculos, $431 \mathrm{C}$ ). En el libro de Artemidoro, que recoge toda la especulación clásica griega y latina sobre el mundo de lo onírico, «el sueño era considerado como un vehículo idóneo para que la divinidad diese a conocer su voluntad ... como portador de un mensaje expresado en clave alegórica» (RUIZ GARCÍA, Elisa. 1989, pp. 19 s.)

El hecho mismo es que hay sueños equivalentes a oráculos y que eso existía en Delfos, como indica la sugerencia - tantas veces repetida- de que el primitivo oráculo de Gea en Delfos fue a través del sueño: ${ }^{38}$ Apolo trajo a Delfos una nueva modalidad de oráculo a través de la enajenación de la Pitia (una especie de delirio equivalente al sueño). Pero hasta la expulsión de las divinidades de la Tierra (tras la victoria de Apolo sobre Pitón, la serpiente ctónica) en Pytho los mensajes del oráculo eran transmitidos por sacerdotes que dormían en el templo de Gea y tenían sueños oraculares. ${ }^{39}$ Hesíodo había hecho hijos de la Noche a la «familia de

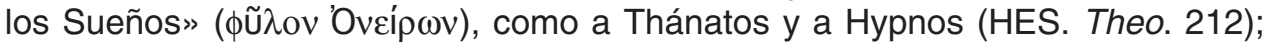
pero no faltaban autores, como Eurípides, que consideraban a la Tierra (Chthôn) causa y madre de los sueños. ${ }^{40}$ La autoridad de esta tradición se pone a veces en duda., pero no hay otro método oracular que sea tan probable. En efecto, ni la profecía inspirada ni la adivinación por suertes son propias de un oráculo de la Tierra; en cambio, ya el autor de Od. 24,12 sitúa el «país de los sueños» en un ambiente ctónico, cerca de los muertos que habitan el seno de Gea. ${ }^{41}$

El sueño oracular era un fenómeno ritual similar al que en la época histórica se practicaba con fines médicos y recibía el nombre de «incubación». La diferencia entre el sueño oracular de Delfos y la incubación tal como se practicaba, por ejemplo, en el santuario de Asclepio en Epidauro, consistía en que en Epidauro no eran los sacerdotes, sino el propio paciente el que refería su sueño. ${ }^{42}$ A veces, como hace Dodds, el nombre de incubación se otorga indistintamente a ambas formas de técnica oracular. ${ }^{43}$

38 «La tradición decía, probablemente con verdad, que el primitivo oráculo de la Tierra en Delfos había sido un oráculo de sueño» (DODDS, E.R. «Esquema onírico y esquema cultural», en The Greeks and the Irrational. The Regents of the University of California, 1951 (trad.castell.: «Los griegos y lo irracional», Madrid. Alianza, 1985, pp.103-131), ver p. 111.

39 «Après I expulsion des divinités chthoniennes dont les messages étaient transmis par des prêtres qui dormaient dans le temple et avaient des songes...» (SCHEFFEER 1943: 153).

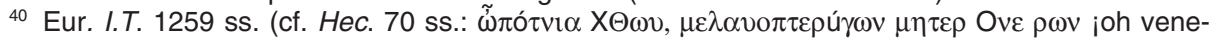
randa Tierra, madre de los sueños de negras alas!).

41 cf. HUNDT, Joachim. Der Traumglaube bei Homer. Greifswald, 1935, p. 74 ss.

42 El templo de Asclepio no era el único en el que se practicaba la incubación: «Así, en algunos oráculos de sueños, ... como en ... el santuario del héroe Anfiarao en Oropo, se requería el ayuno" (DODDS 1951<1985>: 110). Por lo demás, la práctica de la oniromancia permaneció vinculada al entorno del templo. Sabemos que ya en época clásica Lisímaco, pariente de Arístides el Justo, se ganaba el sustento como intérprete de sueños en las inmediaciones del templo de Baco en Atenas y que se servía de una "tabla adivinatoria" (pinákion) para tal cometido" (PLUT. Vida de Arist. 27,3).

43 «La incubación se había practicado en Egipto desde el siglo XV a.C. (en un templo de Amenophis II y Totmes IV para obtener la aprobación del dios de su ocupación del trono) ... Cuando empezamos a encontrarla en Grecia, suele ir asociada con los cultos de la Tierra y de los muertos, que tienen todo el aire de ser prehelénicos; en los tiempos históricos se practicaba la incubación en los santuarios de héroes -fueran éstos hombres fallecidos o demonios ctónicos- y en determinadas grietas o desfiladeros 
Los especialistas en sueños (Aristóteles, Artemidoro, etc.) dividen los sueños en distintos tipos. Uno de estos tipos es el del sueño enviado por los dioses. Vamos por pasos: Antes de llegar a los sueños enviados por los dioses, Artemidoro establece una neta separación entre los sueños de valor profético (óneiroi) y aquellos privados de un mensaje mántico (enýpnia). Los óneiroi a su vez se subdividen en sueños, que son llamados «directos» en los que el contenido del sueño se corresponde con los hechos mismos de los que son premonición; y sueños "simbólicos», que deben ser interpretados mediante un razonamiento, igual que los inconexos oráculos de la Pitia debían ser interpretados por el sacerdocio délfico. En resumen, como sucedía total o parcialmente en relación a los oráculos de Delfos, los sueños simbólicos se presentan en formas incoherentes, embrolladas y en apariencia faltas de sentido. Artemidoro descubre en esos sueños la predicción de un futuro objetivo (a diferencia de Freud, quien — como sabemos_ obtendrá de ellos el conocimiento de unas realidades subjetivas)..$^{44}$

Dentro del tipo de sueños que Artemidoro llama genéricamente óneiroi se da un tercer tipo de sueño específico al que los antiguos daban el significativo nombre de «sueño oracular» chrematismós. E.R.Dodds define este sueño diciendo que «es el que se da cuando en el sueño el padre del soñador, o algún otro personaje respetado o imponente, quizás un sacerdote o incluso un dios, revela sin simbolismo lo que sucederá o no sucederá, lo que debe o no debe hacerse» (DODDS (1951<1985>: 107-108). Aunque en el fondo el resultado es el mismo, hay que distinguir el chrematismós de aquel otro sueño simbólico (óneiros) en que un sacerdote o cualquier otro tipo de intérprete revela, ya en estado de vigilia del soñador, el contenido de un sueño que en la forma se manifestaba enigmático. De este último tipo son los sueños que conocemos en los que podremos más adelante reconocer el tema de la madre Tierra y la marca de Delfos.

Ha sido ya un autor contemporáneo, Dario del Corno, el que se ha servido de la palabra «oniromancia» para referirse al antiguo arte de la predicción del porvenir por medio de la interpretación de los sueños (RUIZ GARCÍA, 1989, p.20). Claro que este tipo de sueños (el óneiros en general y, en especial, el chrematismós ), como los oráculos mismos, tenía entre los antiguos un prestigio o desprestigio propio. Así, a la manera de la misma Yocasta (que ni cree en los oráculos, ni en los sueños, como el supuesto sueño de Edipo de acostarse con su madre, al que trata como un auténtico oráculo, cf. SOPHOCL. Oed.Tyr. 708 ss. y 978 ss.), Aristóteles da cierto crédito a los sueños simbólicos normales, en los que él no reconoce un valor mántico de origen divino. ${ }^{45} \mathrm{Niega}$ que haya sueños enviados por la divinidad $(\theta \varepsilon o ́ \pi \varepsilon \mu \pi \tau \alpha)$ : Si los dioses quisieran comunicar conocimiento a los hombres, lo harían durante el día, y escogerían con más

tenidos por entradas al mundo de los muertos (nekyomanteia). Los Olímpicos no la patrocinaban (hecho que quizá explica suficientemente el silencio de Homero)» (DODDS 1951<1985>: 111).

44 Cf. RUIZ GARCÍA, Elisa. 1989, pp. 35 y 47.

45 «En cuanto a la adivinación que tiene lugar en el sueño $<\ldots>$ no es fácil despreciarla ni darle crédito... en tanto que se dice como consecuencia de una experiencia, ofrece credibilidad» (ARISTOT. Acerca de la adivinación por el sueño, 426b). 
cuidado a los receptores. ${ }^{46}$ Cuando Aristóteles reconoce solamente valor en cuanto sueños simbólicos normales, se acerca a los psicólogos e intérpretes de sueño contemporáneos (Freud, Jung, etc.). Jung razona de la forma siguiente: Puesto que el sueño (simbólico) tiene su punto de partida fundamental en el subconsciente, que contiene las arquetipos colectivos (es como el «mito» de todo un pueblo) y los complejos propios del individuo, es lógico que de alguna forma esté acorde y sea conforme con la personalidad del que sueña, con su carácter (su «daímon», su destino). Y, claro está, el carácter, la personalidad de la persona que sueña, está predisponiendo sus actos futuros. Sólo en ese sentido el sueño es una premonición. ${ }^{47}$

Pero, independientemente del escepticismo de Yocasta y del mismo Aristóteles con respecto a los sueños mánticos, los antiguos creyeron en la oniromancia y en el influjo de ciertas instituciones religiosas ejercieron sobre los sueños simbólicos. En algunos casos se puede poner de relieve que una cultura globalmente considerada o, concretando más, un santuario - como Delfos- dentro de una cultura, tienen un «estilo» específico y propio en la forma de «dar» y de interpretar los oráculos. Justamente la decadencia de la fe en esa cultura religiosa, en general, o en ese santuario, en especial, es lo que llevó al descrédito de sus oráculos y de sus pautas de interpretación de los sueños. ${ }^{48}$

En el terreno de los sueños es relativamente fácil encontrar representado el tema de la madre Tierra. Pero resulta mucho más difícil situar precisamente en el marco de Delfos los sueños que llevan la impronta de la madre Tierra.

Si la propaganda délfica reivindicaba que todos los hombres, por intermedio de la mujer, procrean en la madre Tierra, es lógico encontrar en la literatura antigua un tipo de sueño correspondiente a este tema conductor. El primero en narrar un sueño semejante es Heródoto en siglo VI a.C. El padre de la Historia refiere un sueño que tuvo Hipias, hijo del dictador ateniense Pisístrato, cuando al frente de un ejército persa se dirigía a reconquistar la ciudad de Atenas, que había expulsado al tirano: «Los bárbaros eran conducidos a Maratón por Hipias, hijo de Pisístrato, que la noche anterior había tenido en sueños una extraña visión. Soñó que yacía en brazos de su madre e interpretó que el sueño significaba que iba a ser restaurado como soberano de Atenas y recobrar el poder que había perdido, y que después viviría hasta una edad avanzada en la tierra que le había visto nacer» (HEROD. VI,

46 ibid. 463b 15 ss.; 464a 20 ss.

47 «El hecho de que una opinión («los sueños son significativos») sea tan antigua y tan general, demuestra necesariamente que de algún modo tiene que ser verdadera, esto es, psicológicamente verdadera. Para la actitud moderna resulta apenas concebible que un dios existente fuera de nosotros provoque el sueño, o que éste vaticine proféticamente el porvenir. Mas si la formulamos psicológicamente, la antigua concepción nos resulta ya mucho más comprensible, a saber: el sueño surge de una parte del alma que no conocemos y se ocupa de la preparación del día siguiente y de sus acontecimientos» (C:G. JUNG. 1911 Symbole der Wandlung. Walter -Verlag A.G.Olten (trad.castell.: «Símbolos de Transformación». Barcelona, Paídos 1963,) p. 31-32.

48 «En muchas sociedades primitivas hay ciertos tipos de estructura onírica que dependen de un esquema de creencias socialmente transmitido, y que dejan de darse cuando dejan de ser vigentes dichas creencias» (DODDS 1951<1985>: 104). 
107). Es evidente que en este sentido la madre se eleva al nivel exclusivo de la tierra nativa, es decir la tierra que a uno le ha visto nacer, la patria. Pero estamos ya en el terreno de la Tierra, madre universal. No obstante, el sueño podía ser más preciso en dos puntos: ¿es la madre patria -Atenas en el caso de Hipias, la madre universal Tierra?, y ¿qué significa abrazar a la madre Tierra? Es evidente que en el caso de Hipias, aspirante al poder tiránico sobre Atenas, el abrazo con la madre Tierra no era signo de amor fraterno sino señal de violencia y fuerza.

Y en efecto, cuando muchos siglos después los historiadores romanos imitan a Heródoto, renovando el sueño de Hipias, que ahora es soñado por Cayo Julio César, los signos de violación se hacen manifiestos en el relato, aunque luego fueran ignorados por la interpretación del sueño a la que se acogió el futuro dictador de Roma. César comparte una vivencia similar a la de Hipias, el hijo de Pisístrato, en la biografía que de él escribe Suetonio. La diferencia reside en que, siendo Roma en tiempos de Julio César señora de todo el mundo conocido, la tierra madre con la que César se a cuesta en sueños- se identifica aquí no con la tierra de los padres, la tierra patria, sino la tierra con mayúsculas, la Terra (Gea) que es la madre de todos los hombres. Durante su estancia como pretor en España, a donde fue destinado al inicio de su carrera militar (66 a.C.), César visitó en Cádiz el templo de Hércules (el antiguo dios Melkart fenicio). Allí, al contemplar una estatua de Alejandro Magno, el joven militar romano se lamentó de no haber hecho aún nada memorable en una edad en la que ya Alejandro había sometido a todo el mundo conocido. Pero lo que aquí viene al caso es lo que a renglón seguido añade Suetonio: «Ya los adivinos le habían hecho concebir las más altas esperanzas por un sueño que había tenido la noche anterior, que le había hecho quedar turbado, pues le había parecido forzar sexualmente a su propia madre. En efecto, ellos interpretaron esta visión como un presagio de dominio del mundo, pues aquella madre que había soñado poseer no podía ser otra que la Tierra, madre común de todos los hombres" ${ }^{49}$ El texto de Suetonio no apunta signo alguno de que César entendiera en el sueño un reproche por tomar posesión violenta de su madre, la tierra de Italia y todo el orbe. Y así lo entendieron historiadores y onirocríticos posteriores.

Que está identificación de la madre con la tierra patria, sometida por la fuerza, no es una interpretación exclusiva de Suetonio (y de Plutarco), lo prueba el onirocrítico griego del siglo II d.C. Artemidoro en su libro sobre la «Interpretación de los

49 Etiam confusum eum somnio proximae noctis (nam visus erat per quietem stuprum matri intulisse) coniectores ad amplissimam spem incitaverunt, arbitrium terrarum orbis portendi interpretantes, quando mater, quam subiectam sibi vidisset, non alia esset quam terra, quae omnium parens haberetur (SVET. Iulius Caesar 1,7). Plutarco refiere el mismo sueño de César, pero lo sitúa en el año 49 a.C. en el momento de pasar el Rubicón, cuando César se dispone a conquistar su patria, Italia, disputándosela a Pompeyo (PLUT. Caes. 32, p. 723). La diferencia es notable: en el relato de Plutarco la madre simbolizada en el sueño de César es sólo su patria, Italia; en el sueño relatado por Suetonio (a quien sigue Dión Casio 37,52) lo que se promete a César es el dominio del mundo. La madre con la que César sueña en España no es sólo Italia, es la Tierra Madre universal. En interpretación de muchos historiadores contemporáneos, César no había de ser un tirano al uso, ni lo que le movía era una desmesurada ambición por adueñarse de su madre patria: Su dictadura apuntaba a inaugurar un nuevo orden que afectara a la tierra entera y repartiera el poder entre Roma y los ciudadanos de sus Provincias. 
sueños». El capítulo 79 del libro I de su obra («Relaciones sexuales con la madre») adopta la misma actitud benévola ante quienes toman posesión violenta de su propia madre. Dejamos de lado los párrafos que se refieren al mero incesto con la madre física. El primero de los textos que nos interesan alude al incesto con la madre patria: «Si una persona posee a su madre estando cara a cara con ella y con su cuerpo extendido sobre el de ella, en la posición que algunos llaman conforme a naturaleza (...), es beneficioso para todo cabecilla popular y hombre político en tanto que la madre simboliza a la patria». Aquí Artemidoro alude sin duda a los textos citados, Heródoto y Suetonio a propósito de Hipias y de Julio César respectivamente, cuyo contenido seguramente no desconocía. «Al igual que el individuo que practica el amor, de acuerdo con la norma de Afrodita, posee el cuerpo entero de su compañera con su consentimiento y de buen grado -añade Artemidoro-, así el que tenga este sueño se colocará al frente de todos los asuntos de la ciudad». Artemidoro no precisa la forma de gobierno que adoptará quien haya soñado que se acostaba con la propia madre. Podemos, por consiguiente, concluir que en opinión de Artemidoro soñar el incesto materno simboliza la tendencia a ocupar el poder regio. No menciona expresamente la forma violenta de poseer a la madre, pero en tanto no ignora seguramente el texto de Suetonio, podemos estar seguros de que Artemidoro lo supone y, callando, otorga.

Muy distinta es la actitud que Platón adoptará al respecto del texto de Heródoto. Platón mismo parece haber intuido la existencia de estos deseos incestuosos reprimidos que constituyen la base de la teoría psicoanalítica. Si ello es así, el filósofo ateniense habría anticipado al menos los fundamentos del psicoanálisis freudiano. En su libro IX de la «República» Platón se refiere a los deseos irrefrenados del aspirante a tirano, al que llama «hombre tiránico» (PLAT. Rep. 571 a).

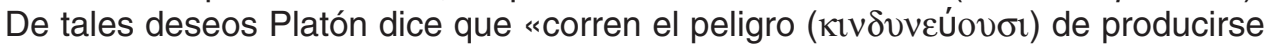
en todos los humanos; pero, reprimidos por las leyes y los deseos mejores con ayuda de la razón, en algunos de los hombres se retiran totalmente o disminuyen en cantidad y fuerza...» (ibid. 571 b). Cuando se le pregunta a qué deseos se refiere, Platón responde:

"Los que surgen en el sueño, cuando duerme la parte del alma razonable, tranquila y buena rectora de lo demás y salta lo feroz y salvaje de ella, ahíto de manjares o de vino, y, proyectándose en el sueño, trata de saciar sus instintos $(\eta \theta \eta)$. Bien sabes que en tal estado se atreve a todo, como liberado y desatado de toda vergüenza y sensatez: no se reprime de copular ( $\mu \varepsilon \imath \gamma v v \sigma \theta \alpha \mathrm{l})$ con su madre, según piensa, o con cualquier otro ser, humano, divino o bestial, ni de mancharse con la sangre de quien sea...» (ibid. $571 \mathrm{c}-\mathrm{d}$ ).

¿Es, pues, Platón un precursor del «complejo de Edipo»? Platón no habla de un componente psíquico de todos los hombres, sino de un «peligro», lo que para cada hombre concreto no pasa de ser una cierta probabilidad. El psicoanálisis no excluye a nadie del complejo de Edipo, al menos en una fase de su vida. Queda claro en Platón que esos deseos (de los que trata el psicoanálisis: copular con la madre, mancharse con la sangre de quien sea -incluido el padre-) «en algunos de los hombres se retiran totalmente o quedan reducidos en cantidad y fuerza». Vi- 
gencia, represión y liberación del deseo incestuoso son momentos clásicos en el análisis del complejo de Edipo que sin duda aparecen bien explícitos en el texto de Platón. Pero, ¿no se trata de un complejo de deseos no comunes ( $\pi \alpha \rho \alpha v o \mu o r$, ..«anormales»)? Aun cuando Platón introduce el tema refiriéndose exclusivamente al hombre tiránico, se insiste más adelante en el texto en «que hay en todo hombre, aun en aquellos de nosotros que parecen mesurados, una especie de deseos temible, salvaje y contra ley, y que ello se hace evidente en los sueños" (ibid. 572 b). Si combinamos ambos textos (Repub. 571 b y 572 b) parece recto concluir que esta "especie de deseos» queda muy reducida en los más mesurados y que Platón la sitúa con todo rigor en aquellos que pasan por encima (o por debajo) de los límites que impone la Polis.

Platón fue más lejos. En este nivel, para el filósofo de Atenas el sueño de acostarse con la madre — someter a la madre - puede simbolizar la ambición tiránica, como resulta explícito en el caso de Hipias, hijo de Pisístrato, tirano de Atenas. Hemos visto más arriba que Platón, aunque en cierta medida admitió en todo hombre la pasajera emergencia y represión de ciertos deseos monstruosos, entre los que se incluía el instinto de acostarse con la propia madre, personalizó de forma específica en el tirano la tendencia permanente a materializar tales deseos. Es más no han faltado autores, como Marie Delcourt, que de entre todos esos deseos mencionados por el filósofo de Atenas, han reducido exclusivamente al hombre tiránico el deseo de acostarse con la madre..$^{50}$ Quizá se pueda objetar a Marie Delcourt el hecho de que Platón, en las páginas siguientes, atribuye a todo hombre enamorado una componente tiránica. Aquella excepcionalidad por la que Platón excluía del incesto materno, entre otros deseos desordenados, al hombre mesurado, desaparece cuando el filósofo se enfrenta a la consideración del hombre enamorado:

«Así, pues, amigo, el hombre se hace con todo rigor tiránico, cuando por su naturaleza o por sus modos de vivir o por ambas cosas, resulta borracho o enamorado o loco. ¿Y no es ésta la razón de que, desde antiguo, Eros sea llamado tirano?» (PLAT. Repub. IX, 573 c y b respectivamente).

La equiparación del enamoramiento a la embriaguez o a la locura parecería avisarnos de que aquí Platón no nos habla meramente de un enamorarse al uso, sino de un amour fou o, dicho con más crudeza, de un amor cargado de sado-masoquismo o de cualquier tipo de violencia de género. La mención de Eros, del Amor a secas sin ninguna especificidad adicional, nos sugeriría un amor mesurado como el que por otra parte se exalta en el diálogo sobre el Amor, el «Simpo-

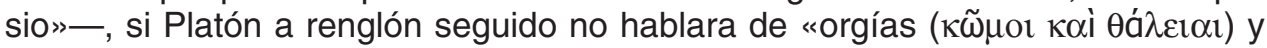

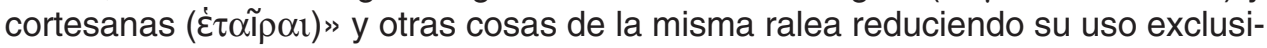
vamente a «aquéllos en cuyo interior habita el tirano Eros gobernando toda el alma» (PLAT. Repub. 573 d). Pensamos, pues, que en la mente de Platón el

50 «Je pense cependant que le détail de I'union avec la mère n'a pas eté suggeré à Platon par une observation psychologique, mais par la tradition historique: il pense au rêve d'Hippias, à l'inceste de Periandre» (Marie Delcourt, Oedipe ou la légende du conquerant, Les Belles Lettres, Paris 1944, p. 202). 
sueño de copular con la madre es exclusividad de los excesos del tirano y que tiene razón Marie Delcourt cuando concluye: «Artemidoro dice que uno llegará a reinar si ha soñado que iba a desposar a su madre; para Platón uno desposa a su madre porque es un tirano". ${ }^{51}$ Lo que sin duda vale también para el sueño en que Yocasta refiere que muchos, como su marido (e hijo) Edipo, se han acostado con la propia madre (SOPHOCL. Oed.Tyr. 980-982). Cuando Yocasta advierte a su hijo Edipo, en el famoso pasaje de Sófocles, «que no tema las bodas con su madre», sin duda se refiere - no a ella misma, lo que sería monstruoso - sino a la madre Tierra. Sófocles no ignoraba el texto citado de Heródoto y el tema de la simbolización de la tiranía como incesto materno. Pero Yocasta ha asimilado ya internamente a la tiranía su reinado, ya tan largo, sobre Tebas y personalmente ha ido superando todos los obstáculos, obstáculos como el que ahora deberá superar Edipo Tirano: «Pero a quien esto es igual que nada, ése lleva la vida de modo más fácil» (ibid. 983).

En el Edipo Rey de Sófocles la reina Yocasta ejerce como antítesis a la propaganda délfica: Ella no cree en el oráculo que Apolo administra por medio de la Pitia, ni teme los excesos tiránicos que el lema délfico prohíbe ( $\mu \eta \delta \varepsilon v \alpha \gamma \alpha v)$, como el que constituye la esencia de la hybris tiránica. Ya en esto descubrimos en el sueño tiránico la presencia de un tema constitutivamente délfico. Pero eso no es todo. Los historiadores que van de Heródoto a Plutarco, y el mismo Platón, han puesto en evidencia el aspecto negativo de la violación de la madre Tierra. Pero, en el ideario délfico, procrear en la madre Tierra y amarla era un tema que debía destacar por sus aspectos positivos. Si Heródoto - al que otros siguieron- escogió destacar un aspecto negativo, la relación violenta con la madre Tierra, otros autores hubieron de poner de relieve la relación benéfica de todos los que procrean - y en especial del político- con la madre Tierra. Nos ha quedado de ello indicio suficiente:

Tito Livio $(1,56)$ ofrece su versión del tema a propósito de Tarquino el Soberbio, el último rey de Roma. El viejo monarca etrusco, avisado por cierto prodigio —una serpiente que se había deslizado de una columna del palacio-, envía a consultar el oráculo de Apolo en Delfos a sus dos hijos Tito y Arrunte, y en compañia de ellos a su sobrino Junio Bruto, quien, haciéndose pasar por oligofrénico, aspiraba sin embargo a arrebatar a Tarquino el poder absoluto para devolverlo al pueblo de Roma (de hecho Junio Bruto había de ser el primer cónsul de la naciente República Romana). Llegados a Delfos, los príncipes cumplen el encargo de su padre. Pero, a continuación, no se sustraen al deseo de interrogar a la Pitonisa sobre quién de ellos heredaría el reino. La sacerdotisa de Apolo les hizo llegar desde el interior de la cueva una voz misteriosa, que los hijos de Tarquino, incautos, interpretaron al pie de la letra:

«Tendrá el poder supremo de Roma, quien de vosotros, oh jóvenes, sea el primero en besar a la madre» (v. 10). Los dos hijos de Tarquino, después de con-

51 Artémidore dit qu on régnera si I'on a revé qu’on épousserait sa mère; pour Platon on épouse sa mère parce qu'on est un tyran» (Marie DELCOURT, op. cit., p. 202). 
jurarse para no comunicar el contenido del oráculo a su hermano mayor, Sexto, heredero del reino, que había quedado en Roma, deciden echar a suertes quién será el primero, cuando regresen a Roma, en dar un beso a su madre, la esposa de Tarquino. Poro Bruto, que era mucho más inteligente que sus dos primos, cayendo en la cuenta de que la Pitia solía hablar en sentidos ambiguos, «se deja caer, como si hubiera tropezado, y da en seguida un beso a la tierra, sabiendo que ella es madre común de todos los mortales" (scilicet quod ea communis mater omnium mortalium esset, v.12).

La tradición histórica, de que Tito Livio se hace eco, tachaba sin vacilar de tiranía el régimen monárquico que los etruscos implantaron en Roma; y Tito Livio sin ninguna vacilación toma por un tirano a Tarquinio el Soberbio. Teniendo en cuenta que los hijos de Tarquino, a quienes directamente atañía el oráculo, aspirarían a heredar la tiranía de su padre, podría parecer que el oráculo de los Tarquinos es equiparable a sueño de Hipias, y que no hemos sobrepapasado el nivel de los tiranos que - como en el texto de Platón- ansían apoderarse de su madre patria. Pero aquí el poder iba a escapar de manos del tirano y a un régimen de concentración de poderes, la monarquía absoluta de los Tarquinos, estaba a punto de suceder un régimen de libertades, la República Romana. Por eso, hay que notar con mayor razón que Junio Bruto interpreta que la madre de que el oráculo de Delfos habla no simboliza meramente a la patria (como en el relato de Heródoto a propósito de Hipias, o en el relato de Plutarco a propósito de César en el paso del Rubicón), sino a la común madre de todos, la Tierra. Con estos presupuestos la historia que Tito Livio cuenta se carga de significado, pues pone de manifiesto el paralelismo onírico-mántico en cuanto el simbolismo positivo de la unión con la madre Tierra. En ese sentido, la mención expresa del santuario de Delfos - que está ausente en Heródoto y los autores que le siguen- es concluyente. El oráculo dado a los hijos de Tarquino el Soberbio, que parte de un sueño de su padre, y que enlaza con el tema de la madre Tierra como origen de la conquista del poder político, pone de manifiesto que ya en Heródoto - y los que le siguen- el sueño del incesto materno no se entiende sin una relación con Delfos: También en los sueños la madre puede valer y vale, no por la mera madre biológica, sino por la madre Tierra. Y, sobre todo en el caso de Yocasta, la mención de las bodas con la madre es, sin duda, una mención al tema de la madre Tierra en el oráculo de Delfos.

\section{BIBLIOGRAFÍA}

AMANDRY, P. La mantique apollinienne à Delphes. Paris, Boccard 1950.

BJÖRCK, G. «Onar ideîn. De la perception de rêve chez les anciens». Eranos 44 (1964) 306314.

BOSCH-VECIANA, Antoni. La saviesa nascuda en el Temple de Delfos: Plató, "Apologia de Sòcrates", 20d8: Lliço inaugural del curs acadèmic 2006-2007. Facultat de Teologia de Catalunya, Barcelona, 2006.

BRAVO, A. «La interpretación de los sueños: onerocrítica griega y análisis freudiano». Tradición clásica y siglo XX. Madrid 1986, 125-141. 
BRISSON, Luc. Platon. Apologie de Socrate. Criton. Traductions inédites, introduction et notes pas Luc Brisson. Paris. Flammarion, 1997.

CORNO, Dario del. Graecorum de re onerocritica scriptorum reliquiae. Mllano-Varese, 1969. CRAHAY, Roland. La littérature oraculaire chez Hérodote. Paris. Les Belles Lettres, 1956.

DARAKI, Maria. Dionysos et la déesse Terre. Flammarion, Paris 2005 (trad.castell.: «Dioniso y la diosa Tierra", Abada ed., Madrid 2009),

DEFRADAS, Les thémes de la propagande delphique. Paris, 1954.

DELCOURT, Marie.

1944 Oedipe ou la légende du conquerant, Les Belles Lettres, Paris 1944

1955 L oracle de Delphes. Paris, 1955.

DODDS, E.R. «Esquema onírico y esquema cultural», en The Greeks and the Irrational. The Regents of the University of California, 1951 (trad.castell.: «Los griegos y lo irracional», Madrid. Alianza, 1985, pp.103-131).

DORION, Louis André. «La subversion de I'elenchos juridique dans I Apologie de Socrate», Révue philosophique de Louvain 88 (1990), pp. 311-344.

FERNÁNDEZ DELGADO, José Antonio. «Poesía oral mántica en los oráculos de Delfos». Symbolae Ludovico Mitxelena septuagenario oblatae. Vol I, 1985, pp. 153-166.

FONTENROSE, Josef.

1959 Python: A Study of Delphic Myth and its Origins. Berkeley: Los Angeles: University of California Presse, 1959.

1978 Oracles.Delphic Oracle. Its Responses and Operations. With a catalogue of Responses. University of California Press. Berkely and Los Angeles 1978.

FRNKFORT, Henri. Kingship and the Gods. University of Chicago, 1948 (trad.castell.: «Reyes y Dioses. Alianza ed., Madrid 1983).

GARCÍA CALVO, Agustín. Razón común. Heráclito. Lucina, Madrid 1985.

GUARDUCCI, M. «Creta e Delfi». Studi e materiali di storia della religione. 19-20, 1943-1946, pp. 85-114.

HARRISON, Jane Ellen.

1907 Prolegomena to the Studiy of Greek Religion. Merlin Press, London 1907.

1911 Themis.A Study of the Social Origin of the Greek Religion. Merlin Press, London 1911.

HERNÁNDEZ DE LA FUENTE, David. Oráculos griegos, Alianza ed. Madrid 2008.

HUNDT, Joachim. Der Traumglaube bei Homer. Greifswald, 1935.

MAYOR, Domingo.

1948 Sófocles: Edipo Rey. Edición y estudios. Universidad Pontificia de Comillas. Santander, 1948.

1953 La Tragedia Griega. Traducciones. Estudios. Universidad Pontificia de Comillas. Santander, 1953.

MILLER, Andrew M. From Delos to Delphi. A literary study of the Homeric Hymn to Apollo. Brill. Leiden, 1986.

MORET, Jean-Marc. Oedipe, la Sphinx et les Thébains. Essai de mythologie iconographique. I-II, Genève, Institute suisse de Rome,1984.

OTTIS, Brooks. Cosmos and Tragedy. An Essay on the meaning of Aeschylus. The University of Carolina Press. Chapel Hill, 1981.

OWEN, E.T. The Harmony of Aeschylus. G. Bell and Sons, London, 1952.

PARKE, H.W. A History of the Delpfhic Oracle. Oxford 1939.

PARKE, H.W y WORMELL,D.E.W. The Delphic Oracle. 1956.

PLUTARCO. Moralia VI, («La E de Delfos», «Los Oráculos de la Pitia», y «La desaparición de los oráculos»), Ed. Gredos, Madrid 1995

PORDOMINGO PARDO, Francisca, y FERNÁNDEZ DELGADO, José Antonio: introducción, traducción y notas de Plutarco, Moralia VI, Ed. Gredos, Madrid 1995.

ROBERT,Carl. Oidipus. Geschichte eines poetischen Stoffes in griechischen Altertum. Berlin: Weidmann, 1915 
ROSCHER, Wilhelm.

1890-1921 Lexikon der Griechischen und Römischen Mythologie. Leipzig. Teubner, 18901921.

1913 «Omphalos». Abhandl. sächs. Ges. Wiss. 29, 1913.

1915 «Neue Omphalosstudien». Abhandl. sächs. Ges. Wiss. 31, 1915

ROUX, Georges. Delphi: Orakel und Kultstätten. Ed. Hirmer. München, 1971. (UPCO: 0821020).

RUIPÉREZ, Martín S. El mito de Edipo. Lingüistica, psicoanálisis y folklore. Madrid. Alianza, 2006

RUIZ GARCÍA, Elisa. Introdución traducción y notas. Artemidoro. Interpretación de los sueños. Madrid. Gredos, 1989, pp. 19 s.

SCHEFFER, Thassilo de. Mystères et oracles helléniques (traducción francesa del profesor André Sandt). Payot. Paris, 1943.

SUÁREZ DE LA TORRE, E. «Sueño y fenomenología onírica en Aristóteles». Cuad. de Fil. Clás. 5 (1973), 279-311.

VERNANT, J.-P.

1960 y 1966 Mito y pensamiento en la Grecia antigua, Ariel, Barcelona 1983, pp. 21-88.

1981 «Oedipe». Dictionnaire de Mythologies. Paris. 1981, pp. 241-242..

VERNANT, J.P./NIDAL NAQUET,P. Mythe et tragedie en Grèce ancienne. Tomo I: Paris, Librairie François Maspero 1972. Tomo II: Editons La Découverte, Paris 1988 (trad, castell,: «Mito y tragedia en la Grecia antigua», Taurus ed., Madrid 1989, t. I y II).

VERRALL, A.V. ed. The Eumenides of Aeschylus. London, 1908. 
